\title{
Explanation of industrial analyses
}

\section{Input-Output Supply and Use Tables}

The annual estimates prepared for the Blue Book incorporate the results of annual inquiries which become available in the first part of the year, although estimates for the latest year are still based largely on quarterly information. As new data are collected it is likely that revisions will be necessary. The process of reassessing these estimates involves the preparation of Supply and Use Tables. This approach amalgamates all the available information on inputs, outputs, gross value added, income and expenditure. Similarly the production of the consolidated sector and financial accounts requires the preparation of 'top-to-bottom' sector and sub-sector accounts to identify discrepancies in the estimates relating to each sector. The thorough and detailed nature of this estimation process require a large amount of time and resource and so estimates for earlier years are not normally revisited unless there are strong reasons for doing so.

\section{GDP and the balancing of the annual accounts}

As discussed in Part 1, there are three different approaches to the estimation of current price GDP in the UK: the income approach, the expenditure approach and the production approach. In theory the three different approaches should produce the same result. However, the different approaches are based on different surveys and administrative data sources and each produces estimates which, like all statistical estimates, are subject to errors and omissions. A definitive GDP estimate can only emerge after a process of balancing and adjustment. ONS believes that the most reliable 'definitive' estimate of the current price level of GDP is that derived using the annual Supply and Use Tables framework. Thus, for the years when Supply and Use Tables are available, GDP is set at the level derived from that year's balance. For periods subsequent to the latest Supply and Use Tables, the level of GDP is carried forward using movements in income, expenditure and production totals.

\section{The Supply and Use framework}

The accounting framework shown in Figure 1 in the Introduction is mainly concerned with the composition and value of goods and services entering into final demand (for example, purchases by consumers) and the outputs and incomes generated in the production process. It does not display the inter-industry transactions which link these activities.

The UK Supply and Use Tables, however, do include these intermediate transactions which form inputs into these processes, thus providing an extra dimension. The analyses are constructed to show a balanced and complete picture of the flows of products in the economy and illustrate the relationships between producers and consumers of goods and services. On an annual basis, Supply and Use Tables are used to achieve consistency in the economic accounts' aggregates by linking the components of value added, inputs, outputs and final demand. As the income, production and expenditure measures of GDP can all be calculated from the Supply and Use Tables, a single estimate of GDP can be derived by balancing the supply and demand for goods and services and reconciling them with the corresponding value added estimates. For the years 1989 to 2006, the balancing process has been used to set the level of current price GDP and has disposed of the need for statistical discrepancies in the form of a GDP expenditure adjustment and a GDP income adjustment.

\section{Industrial analyses}

The process, which produces Supply and Use Tables annually, has been speeded up considerably over the last few years and can now produce the first balance for a year around eighteen months after the end of that year. These full Supply and Use Tables, consistent with the National Accounts Blue Book, are published as a separate web-only publication at the same time as the Blue Book. The latest annual Supply and Use tables ${ }^{1}$ cover the periods 2004 to 2006, with summary information provided in the Blue Book itself.

\section{Some background on the structure of the} Supply and Use Tables

The Supply and Use Tables are based on a framework which incorporates estimates of industry inputs, outputs and value added. The tables consist of two matrices: the Supply matrix 
and the Use matrix, each of which breaks down and balances 108 different industries and 123 products at purchasers' prices. The following paragraphs summarise the methodology. For more detail see Akers and Clifton-Fearnside (2008). ${ }^{2}$

\section{Supply table}

At a very aggregate level the Supply table can be represented as follows:

\begin{tabular}{|l|l|l|l|l|}
\cline { 2 - 4 } \multicolumn{1}{c|}{} & $\begin{array}{l}\text { Output by } \\
\text { industry }\end{array}$ & $\begin{array}{l}\text { Imports of } \\
\text { goods and } \\
\text { services }\end{array}$ & $\begin{array}{l}\text { Dis- } \\
\text { tributors' } \\
\text { trading } \\
\text { margins }\end{array}$ & $\begin{array}{l}\text { Taxes } \\
\text { less } \\
\text { subsidies } \\
\text { on } \\
\text { products }\end{array}$ \\
\hline $\begin{array}{l}\text { Output } \\
\text { by } \\
\text { product }\end{array}$ & & & & \\
\hline
\end{tabular}

The main part of the Supply table shows estimates of domestic industries' output (total sales adjusted for changes in inventories of work in progress and finished goods) compiled at basic prices. Basic prices value the goods leaving the factory gate but exclude any taxes on products and include any subsidies on products. However, for the balancing process, the estimates of supply of products are required at purchasers' prices, that is, those actually paid by the purchasers to take delivery of the goods, excluding any deductible VAT. To convert the estimates of domestic output valued at basic prices to the total supply of products valued at purchasers' prices requires the addition of:

- the value of imports of goods and services

distributors' trading margins

- taxes on products (for example, VAT, excise duties, air passenger tax, insurance premium tax etc)

less

- subsidies on products (for example, agricultural and transport subsidies)

\section{Use table}

The Use table reveals the input structure of each industry in terms of combined domestic and imported goods and services.
It also shows the product composition of final demand and, for each industry, the intermediate purchases adjusted for changes in inventories of materials and fuels. Consumption of products is represented in the rows of the balance while purchases by industries, and final demands, are represented in the columns. At a very aggregate level the Use table can be considered in three parts as shown below.

The body of the matrix, which represents consumption of products, is at purchasers' prices and so already includes the product-specific taxes and subsidies separately added in the Supply table.

The Supply-Use balance is effectively achieved when:

For industries:

Inputs (from the Use table)

equals

Outputs (from the Supply table)

For products:

Supply (from the Supply table)

equals

Demand (from the Use table)

That is, when the data from the income, expenditure and production approaches used to fill the matrices all produce the same estimate of current price GDP at market prices. GDP at current market prices can be derived from the balances by taking the estimate of total gross value added at basic prices (from the Use table) and adding taxes on products and deducting subsidies on products (from the Supply table).

\section{The BB08 balancing process}

The supply and use tables produced this year will appear little different to those of the past, in terms of level of detail and coverage. What is being published this year provides the foundation for future improvements. What is fundamentally different this year is the process used to balance the supply and use tables. Previously balancing supply and use tables has been achieved by means of a dedicated central team. Their role was to maintain the system to bring together all the data sources necessary to populate the supply and use framework and Industry consumption/final demand table

\begin{tabular}{|l|l|l|}
\cline { 2 - 3 } \multicolumn{1}{c|}{} & Industry consumption & Final demands \\
\hline Products consumed & $\begin{array}{l}\text { Shows consumption by each industry to } \\
\text { produce their own output } \\
\text { (that is, intermediate consumption) }\end{array}$ & $\begin{array}{l}\text { Shows final demand categories (for example, } \\
\text { households' expenditure) and the values of } \\
\text { products going to these categories }\end{array}$ \\
\hline Primary inputs & $\begin{array}{l}\text { Shows the gross value added components } \\
\text { of each industry, taxes less subsidies on } \\
\text { production other than product specific } \\
\text { taxes and subsidies, compensation of } \\
\text { employees and gross operating surplus. }\end{array}$ & \\
\hline
\end{tabular}


produce a balance. A detailed description of the methods and process used previously can be found in Mahajan (2006). ${ }^{3}$

For this year's Blue Book we have used a more decentralised approach to balancing. The sources of data used to populate the supply and use framework have not changed significantly although the computing systems used to marshal together the data and represent the supply and use framework are new. These new systems are an output from the ONS programme for the modernisation of its statistical systems and processes. The process of balancing is, however, somewhat different to what has been done in the past. Balancing no longer relies on a separate team allocated specifically to balancing the supply and use tables. Those involved in balancing are the compilers of the basic data that form the input to the process. These individuals bring with them an understanding of the data that is being used to populate the supply and use framework. If we considered the supply and use framework as a column (industry) and row (product) matrix the confrontation of the data can be viewed as a process of separate column, row and column confrontations of the data.

The process used to produce and balance the national accounts in the past has relied on the knowledge and experience of a small group of people. The new process aims to open up the process and make it more transparent. In this way we aim to place less reliance on specific individuals, thus ensuring our ability to balance in the longer term is more secure. Also, by including more individuals in the balancing process we hope to benefit from the wider experience those involved bring to the process.

The first interrogation of data takes place before the supply and use framework is populated. It consists of an examination of the columns in the framework being reviewed for plausibility independently of each other. For example, estimates of household consumption expenditure, by product, are produced and analysed to ensure the overall picture of household spending and its breakdown by product presents a credible story in their own right. Similarly, for those components with an industry dimension, such as output, the initial stage scrutinises these data to ensure the story for industries look plausible. This first stage of confrontation is carried out by the compilers of the original data.

The second stage is a confrontation within the framework of the rows (products) in the supply and use framework. This challenges the data in each row with the aim of achieving a balance across the row to ensure that the accounting relationship that the supply of a product is equal to the demand for that product. This process identifies areas of inconsistency between the various sources which can then be investigated. Data within the row are then subsequently adjusted to achieve a balance. This adjustment process reviews the quality of the data used to populate the individual cells within a row and makes use of this information to adjust the original data.

The third stage of the balancing process is to interrogate the columns. Unlike the confrontation within the column, carried out during the first stage this time it is carried out in the context of the supply and use framework. Whilst the second stage of balancing results in a balance of the rows it does not result in satisfying the accounting relationship for the columns. This needs to ensure that for each industry the inputs to the process of production equal its outputs. This third stage of balancing has the objective of confirming that this column identity is satisfied.

Once stage three is complete there is a strong potential that the row identities balanced during stage two of the process will have subsequently been broken. The process of repeating stages two and three continues until both the row and column identities are satisfied or a balance can not be achieved. This iterative process of row and column balancing effectively homes in on a position of balance by way of narrowing the degree of imbalance remaining in the supply and use framework after each balancing cycle. Whilst the description above may seem to indicate a fairly mechanistic balancing approach a significant amount of knowledge of the methods and quality of the basis data are used as part of the process. Alongside this the evolving balance is reviewed at each stage to see how the economic story is developing and make sure that story is credible.

\section{Current price analysis (Tables 2.1, 2.2 and 2.3)}

The analyses of gross value added and other variables by industry shown in Part 2 reflect estimates based on the Standard Industrial Classification (SIC(2003)). Tables 2.1, 2.2 and 2.3 are based on current price data reconciled through the I-O process for 1992 to 2006 . The aggregate figures for the latest year, 2007, as shown in Tables 2.2 and 2.3, are based on data reconciled through the National Accounts balancing process. This process is explained in chapter 11 of Concepts, Sources and Methods. ${ }^{5}$ The industry detail for the year 2007 is based on current price output estimates from a variety of sources, both within ONS and in other government departments. These estimates will be revised when the first I-O Supply and Use Tables for 2007 become available.

Estimates of total output and gross value added are valued at basic prices, the method recommended by ESA95. Thus the only taxes included in the price will be taxes paid as part of the production process (such as business rates and vehicle excise duty), and not any taxes specifically levied on the production of a unit of output (such as VAT). Any subsidies on products received will also be included in the valuation of output. 


\section{Chained volume indices $(2003=100)$ analyses} (Table 2.4)

Table 2.4 shows chained volume estimates of gross value added at basic prices by industry. The basic methodology for these estimates can be found in the Government Statistical Service methodological publications Gross Domestic Product: Output approach. ${ }^{6,7}$ A more detailed explanation is in Concepts, Sources and Methods. ${ }^{5}$

The output approach provides the lead indicator of economic change in the short-term. However in the longer-term, it is required to follow the annual path indicated by the expenditure measure of real GDP (usually within 0.2 per cent of the average annual gross value added growth). To achieve this, balancing adjustments are sometimes applied to the output based gross value added estimates.

An examination of the chained volume gross value added and expenditure measures of GDP shows what are considered to be excessive differences in growth for a number of recent years.

During the five years of 1995 to 1999 the output-based estimate increased more than the expenditure measure.

The output-based estimate grew more slowly than the expenditure measure in the years of 20002002 and $2003^{4}$.

In the years 2001, 2004, 2005 and 2006 output growth was greater than expenditure.

The largest the difference in growth between the output and expenditure GVA measure was 0.6 percent, which occurred over the 1998 year.

To reduce these discrepancies, a number of balancing adjustments have been made to the chained volume gross value added annual growth rates.

Assigning adjustments: improvements for the 2008 Blue Book

For this year's Blue Book, balancing adjustments have been applied on the same basis as for the 2006 Blue Book. For technical and other reasons, the adjustments are not at present made to the non-service industries for any years.

\section{Apportioning between industries}

Under the revisions policy in the 2005 Blue Book, revisions were only permitted for the predominantly 'government' components between 1996 and 2000. Consequently all adjustments to annual growth rates in these years were achieved via the following industries: public administration and defence; compulsory social security (section L), education (section M) and health and social work (section N). In some cases this restriction led to an inappropriate allocation across the components of gross value added.
The revisions policy for the 2006 Blue Book permits revisions to all components. The revision policy for the 2008 Blue Book permits revisions to all components for all years as a result of the allocation of FISIM. This has enabled a more appropriate allocation of the adjustments across industries.

\section{Applying the adjustments}

ONS has developed an automatic function for assigning the annual adjustments to gross value added. This is designed to be as faithful as possible to the quarterly paths whilst adjusting the overall annual growth rate of a group of series. The 2006 Blue Book is the first time that all adjustments to all industries have been assigned using this system. Details of the new adjustments are given below. Using the automatic function produces some differences in the adjustments within the groupings shown. These differences are generally no greater than 0.2 per cent.

\section{For 1995:}

A downward adjustment of 0.6 per cent has been applied to:

distribution, hotels and restaurants; (sections $\mathrm{G}$ and $\mathrm{H}$ )

A downward adjustment of 0.7 per cent has been applied to:

- transport storage and communication (section I)

A downward adjustment of 0.7 per cent has been applied to:

- Business Services and Finance (section J and K)

A downward adjustment of 0.3 per cent has been applied to:

government and other services (sections $L$ to $P$ )

The total effect of these adjustments is to reduce the $1994 / 1995$ growth rate by 0.3 per cent.

\section{For 1996:}

A downward adjustment of 0.6 per cent has been applied to:

- distribution, hotels and restaurants; (sections $\mathrm{G}$ and $\mathrm{H}$ )

A downward adjustment of 0.9 per cent has been applied to:

- transport storage and communication (section I)

A downward adjustment of 0.6 per cent has been applied to:

Business Services and Finance (section J and K)

A downward adjustment of 0.6 per cent has been applied to:

government and other services (sections $L$ to $P$ )

The total effect of these adjustments is to reduce the 1995/1996 growth rate by 0.4 per cent.

For 1997:

A downward adjustment of 0.4 per cent has been applied to: 
- distribution, hotels and restaurants; (sections $\mathrm{G}$ and $\mathrm{H}$ )

A downward adjustment of 0.6 per cent has been applied to:

- transport storage and communication (section I)

A downward adjustment of 0.5 per cent has been applied to:

- Business Services and Finance (section J and K)

A downward adjustment of 0.5 per cent has been applied to:

- government and other services (sections $L$ to $P$ )

The total effect of these adjustments is to reduce the $1996 / 1997$ growth rate by 0.3 per cent.

1998:

A downward adjustment of 0.7 per cent has been applied to:

- distribution, hotels and restaurants; (sections $\mathrm{G}$ and $\mathrm{H}$ )

A downward adjustment of 0.4 per cent has been applied to:

- transport storage and communication (section I)

A downward adjustment of 0.6 per cent has been applied to:

- Business Services and Finance (section J and K)

A downward adjustment of 1.3 per cent has been applied to:

- government and other services (sections $L$ to $P$ )

The total effect of these adjustments is to reduce the $1997 / 1998$ growth rate by 0.6 per cent.

1999:

A downward adjustment of 0.2 per cent has been applied to:

- distribution, hotels and restaurants; (sections $\mathrm{G}$ and $\mathrm{H}$ )

An upward adjustment of 0.1 per cent has been applied to:

- transport storage and communication (section I)

A downward adjustment of 0.3 per cent has been applied to:

- Business Services and Finance (section J and K)

A downward adjustment of 0.3 per cent has been applied to:

- government and other services (sections $L$ to $P$ )

The total effect of these adjustments is to reduce the $1998 / 1999$ growth rate by 0.1 per cent.

2000:

An upward adjustment of 0.1 per cent has been applied to:

- distribution, hotels and restaurants; (sections $\mathrm{G}$ and $\mathrm{H}$ )

An upward adjustment of 0.2 per cent has been applied to:

- transport storage and communication (section I)
A downward adjustment of less than 0.1 per cent has been applied to:

Business Services and Finance (section J and K)

A downward adjustment of less than 0.1 per cent has been applied to:

government and other services (sections $L$ to $P$ )

The total effect of these adjustments is to increase the 1999/2000 growth rate by less than 0.1 per cent.

For 2001:

A downward adjustment of 0.1 per cent has been applied to:

- distribution, hotels and restaurants; (sections $\mathrm{G}$ and $\mathrm{H}$ )

An downward adjustment of 0.2 per cent has been applied to:

- transport storage and communication (section I)

An upward adjustment of less than 0.1 per cent has been applied to:

Business Services and Finance (section J and K)

A downward adjustment of less than 0.1 per cent has been applied to:

- government and other services (sections $L$ to $P$ )

The total effect of these adjustments is to decrease the 2000/2001 growth rate by less than 0.1 per cent.

For 2002:

An upward adjustment of 0.4 per cent has been applied to:

distribution, hotels and restaurants; (sections $\mathrm{G}$ and $\mathrm{H}$ )

An upward adjustment of 0.3 per cent has been applied to:

- transport storage and communication (section I)

An upward adjustment of 0.2 per cent has been applied to:

- Business Services and Finance (section J and K)

An upward adjustment of 0.3 per cent has been applied to:

- government and other services (sections $L$ to $P$ )

The total effect of these adjustments is to increase the 2001/2002 growth rate by 0.2 per cent.

For 2003:

A downward adjustment of 0.6 per cent has been applied to:

distribution, hotels and restaurants; (sections $\mathrm{G}$ and $\mathrm{H}$ )

A downward adjustment of 1.0 per cent has been applied to:

- transport storage and communication (section I) 
An upward adjustment of 0.3 per cent has been applied to:

- Business Services and Finance (section J and K)

An upward adjustment of 0.5 per cent has been applied to:

- government and other services (sections $L$ to $P$ )

The total effect of these adjustments is to increase the 2002/2003 growth rate by less than 0.1 per cent.

For 2004:

A downward adjustment of 0.5 per cent has been applied to:

- distribution, hotels and restaurants; (sections $\mathrm{G}$ and $\mathrm{H}$ )

A downward adjustment of 0.4 per cent has been applied to:

- transport storage and communication (section I)

A downward adjustment of 0.5 per cent has been applied to:

- Business Services and Finance (section J and K)

A downward adjustment of 0.8 per cent has been applied to:

- government and other services (sections $L$ to $P$ )

The total effect of these adjustments is to decrease the 2003/2004 growth rate by 0.4 per cent.

For 2005:

A downward adjustment of 0.5 per cent has been applied to:

- distribution, hotels and restaurants; (sections $\mathrm{G}$ and $\mathrm{H}$ )

A downward adjustment of 0.5 per cent has been applied to:

- transport storage and communication (section I)

A downward adjustment of 0.5 per cent has been applied to:

- Business Services and Finance (section J and K)

A downward adjustment of 0.7 per cent has been applied to:

- government and other services (sections $L$ to $P$ )

The total effect of these adjustments is to decrease the $2004 / 2005$ growth rate by 0.4 per cent.

For 2006:

A downward adjustment of 0.3 per cent has been applied to:

- distribution, hotels and restaurants; (sections $\mathrm{G}$ and $\mathrm{H}$ )

A downward adjustment of 0.3 per cent has been applied to:

- transport storage and communication (section I)

A downward adjustment of 0.3 per cent has been applied to:

- Business Services and Finance (section J and K)
A downward adjustment of 0.2 per cent has been applied to:

- government and other services (sections $L$ to $P$ )

The total effect of these adjustments is to decrease the 2005/2006 growth rate by 0.2 per cent.

\section{Employment analyses (Table 2.5)}

Table 2.5 breaks down employment data into six broad industry groupings. Employee jobs, the main component of the employment figures, uses an industry breakdown which is consistent with most other parts of the National Accounts. This is because employee figures are obtained from surveys of businesses whose details are stored on National Statistics' Business Register. This is the same register which is used for all other business surveys collecting economic data.

The estimates of self-employment jobs come from the Labour Force Survey. This is a household survey which codes respondents according to their own view of the industry in which they work. Because of this, the industrial coding of the self employment jobs may not be consistent with the industrial codes for employees. Note that the data do not include UK armed forces or government supported trainees, which are the other components of the Workforce Jobs series.

\section{References:}

1 Office for National Statistics (2008) Supply-Use Tables 2008: www.statistics.gov.uk/about/methodology_by_theme/ inputoutput/latestdata.asp

2 Akers R and Clifton-Fearnside A (2008) forthcoming.

3 Mahajan S (2006) Compilation and Use of Input-Output Supply and Use Tables in the UK National Accounts Economic Trends No. 634.

4 Office for National Statistics (1998) National Accounts Concepts, Sources and Methods, 1998 edition. The Stationery Office: London.

5 Humphries S (2006) Revisions planned for the 2006 annual Blue Book, Pink Book and Input-Output analyses. Economic Trends No. 629, pp 20-23: www.statistics.gov.uk/cci/article. asp?ID=1476

6 Government Statistical Service (1998) Gross Domestic Product: Output methodological guide.

7 Government Statistical Service (1998) Gross Domestic Product: Output approach (Gross Valued Added). GSS Methodology Series No 15.

8 Office for National Statistics (2000) Review of Short-Term Output Indicators: National Statistics. Quality Review Series Report No. 1. 


\begin{tabular}{|c|c|c|c|c|c|c|}
\hline \multirow{3}{*}{2004} & \multicolumn{6}{|c|}{ SUPPLY OF PRODUCTS } \\
\hline & \multirow{2}{*}{$\begin{array}{r}\text { Domestic } \\
\text { output of } \\
\text { products } \\
\text { at } \\
\text { basic prices }\end{array}$} & \multicolumn{2}{|c|}{ Imports } & \multirow{2}{*}{$\begin{array}{r}\text { Distributors' } \\
\text { trading } \\
\text { margins }\end{array}$} & \multirow{2}{*}{$\begin{array}{r}\text { Taxes } \\
\text { less } \\
\text { subsidies } \\
\text { on } \\
\text { products }\end{array}$} & \multirow{2}{*}{$\begin{array}{r}\text { Tota } \\
\text { supply o } \\
\text { products a } \\
\text { purchasers } \\
\text { prices }\end{array}$} \\
\hline & & Goods & Services & & & \\
\hline \multicolumn{7}{|l|}{ PRODUCTS ${ }^{1}$} \\
\hline Agriculture, forestry \& fishing [1-3] & 21216 & 6142 & 375 & 3858 & -2186 & 29405 \\
\hline Mining \& quarrying [4-7] & 32418 & 14517 & 483 & 1660 & 504 & 49582 \\
\hline Manufacturing $[8-84]$ & 378195 & 228154 & 14862 & 211845 & 78793 & 911849 \\
\hline Electricity, gas \& water supply [85-87] & 49093 & 327 & 55 & - & 1993 & 51468 \\
\hline Construction [88] & 170705 & - & 203 & - & 11980 & 182888 \\
\hline Distribution \& hotels [89-92] & 322862 & - & 13564 & -217363 & 14063 & 133126 \\
\hline Transport \& communication [93-99] & 167696 & - & 18557 & - & 2783 & 189036 \\
\hline Finance \& business services $[100-114]$ & 562881 & 228 & 29567 & - & 15506 & 608182 \\
\hline Public administration \& defence [115] & 115066 & - & 32 & - & - & 115098 \\
\hline Education, health \& social work [116-118] & 225688 & - & 1943 & - & 2148 & 229779 \\
\hline Other services [119-123] & 92483 & 2406 & 4731 & - & 6437 & 106057 \\
\hline Total & 2138303 & 251774 & 84372 & - & 132021 & 2606470 \\
\hline \multicolumn{7}{|l|}{ of which: } \\
\hline Market output & 1766597 & & & & & \\
\hline Output for own final use & 91189 & & & & & \\
\hline Other non-market output & 280517 & & & & & \\
\hline
\end{tabular}

\section{Use Table at Purchasers' prices}

\begin{tabular}{|c|c|c|c|c|c|c|c|c|c|c|c|}
\hline \multirow[b]{2}{*}{2004} & \multicolumn{11}{|c|}{ INTERMEDIATE CONSUMPTION BY INDUSTRY GROUP ${ }^{12}$} \\
\hline & Agriculture & $\begin{array}{c}\text { Mining \& } \\
\text { quarrying }\end{array}$ & $\begin{array}{r}\text { Manufac- } \\
\text { turing }\end{array}$ & $\begin{array}{r}4 \\
\text { Electricity, } \\
\text { gas \& } \\
\text { water } \\
\text { supply }\end{array}$ & $\begin{array}{r}\text { Construc- } \\
\text { tion }\end{array}$ & $\begin{array}{r}6 \\
\text { Distribution } \\
\& \\
\text { hotels }\end{array}$ & $\begin{array}{r}7 \\
\text { Transport } \\
\& \\
\text { communi- } \\
\text { cation }\end{array}$ & $\begin{array}{r}8 \\
\text { Finance } \\
\& \\
\text { business } \\
\text { services }\end{array}$ & $\begin{array}{r}9 \\
\text { Public } \\
\text { adminis- } \\
\text { tration \& } \\
\text { defence }\end{array}$ & $\begin{array}{r}10 \\
\text { Education, } \\
\text { health \& } \\
\text { social work }\end{array}$ & $\begin{array}{r}\text { Other } \\
\text { services }\end{array}$ \\
\hline \multicolumn{12}{|l|}{ PRODUCTS' } \\
\hline Agriculture, forestry \& fishing [1-3] & 2131 & 1 & 9859 & 5 & 215 & 1680 & 42 & 12 & 8 & 211 & 29 \\
\hline Mining \& quarrying [4-7] & 6 & 3332 & 16027 & 11736 & 2612 & 151 & 105 & 8 & 6 & 7 & 21 \\
\hline Manufacturing $[8-84]$ & 5948 & 2188 & 179511 & 3559 & 26910 & 43664 & 20582 & 12239 & 21056 & 27295 & 6500 \\
\hline Electricity, gas \& water supply [85-87] & 428 & 500 & 8528 & 14949 & 276 & 2146 & 927 & 1608 & 1162 & 1706 & 603 \\
\hline Construction [88] & 243 & 851 & 1127 & 752 & 50423 & 1945 & 1923 & 12154 & 4631 & 1206 & 867 \\
\hline Distribution \& hotels [89-92] & 684 & 123 & 1119 & 170 & 1558 & 6938 & 3155 & 5513 & 1631 & 1983 & 682 \\
\hline Transport \& communication [93-99] & 424 & 1267 & 13940 & 496 & 1202 & 31835 & 35071 & 25684 & 4757 & 5896 & 2664 \\
\hline Finance \& business services [100-114] & 2082 & 2891 & 31091 & 3273 & 20760 & 53442 & 25907 & 137995 & 18620 & 18887 & 17427 \\
\hline Public administration \& defence [115] & 12 & 20 & 517 & 35 & 338 & 214 & 1323 & 5351 & 266 & 75 & 66 \\
\hline Education, health \& social work [116-118] & 187 & 32 & 1097 & 154 & 170 & 916 & 1171 & 4847 & 4272 & 29420 & 907 \\
\hline Other services [119-123] & 228 & 90 & 3027 & 184 & 161 & 1848 & 1754 & 3554 & 3264 & 3427 & 15024 \\
\hline Total consumption & 12373 & 11295 & 265843 & 35313 & 104625 & 144779 & 91960 & 208965 & 59673 & 90113 & 44790 \\
\hline Taxes less subsidies on production & -446 & 187 & 2451 & 1275 & 651 & 7655 & 1087 & 2737 & - & 152 & 950 \\
\hline Compensation of employees & 3454 & 3105 & 104260 & 4873 & 31147 & 99529 & 53793 & 146628 & 47599 & 119073 & 34638 \\
\hline Gross operating surplus & 7592 & 19268 & 40550 & 10524 & 32157 & 51517 & 24948 & 172725 & 7794 & 17006 & 19695 \\
\hline Gross value added at basic prices & 10600 & 22560 & 147261 & 16672 & 63955 & 158701 & 79828 & 322090 & 55393 & 136231 & 55283 \\
\hline Output at basic prices & 22973 & 33855 & 413104 & 51985 & 168580 & 303480 & 171788 & 531055 & 115066 & 226344 & 100073 \\
\hline
\end{tabular}




\section{Gross value added at basic prices}

f billion

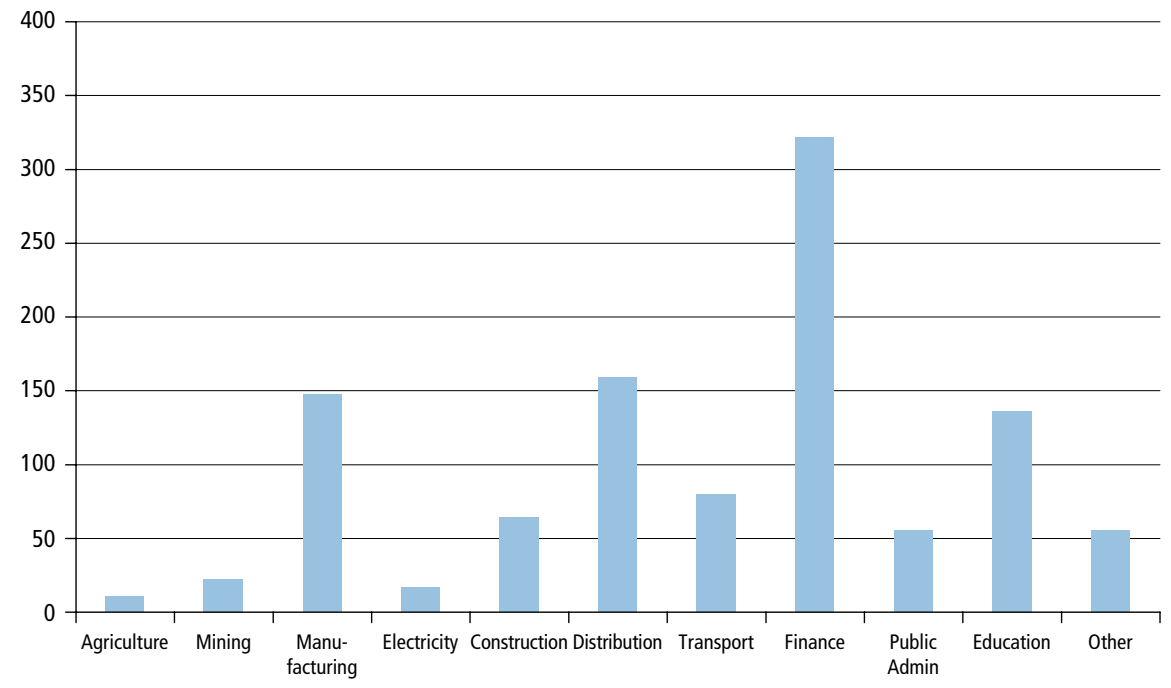

\section{Components of final demand}

Per cent

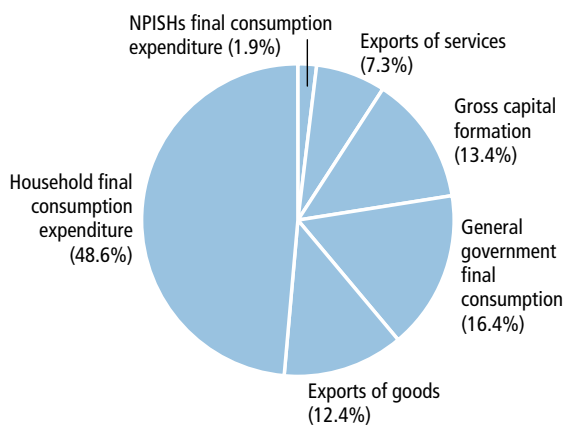

£ million

2004

\section{PRODUCTS}

Agriculture, forestry \& fishing [1-3] Mining \& quarrying [4-7]

Manufacturing [8-84]

Electricity, gas \& water supply [85-87] Construction [88]

Distribution \& hotels [89-92]

Transport \& communication [93-99]

Finance \& business services [100-114]

Public administration \& defence [115]

Education, health \& social work [116-118]

Other services [119-123]

\section{Total consumption}

Taxes less subsidies on production Compensation of employees Gross operating surplus

Households

NPISHs

GFCF Valuables inventories

Goods Services

Gross value added at basic prices

Output at basic prices

$\begin{array}{r}14193 \\ 34011 \\ 349452 \\ 32833 \\ 76122 \\ 23556 \\ 123236 \\ 332375 \\ 8217 \\ 43173 \\ 32561 \\ \hline 1069729 \\ \hline 16699 \\ 648099 \\ 403776 \\ \hline 1068574 \\ \hline 2138303 \\ \hline\end{array}$

\begin{tabular}{rrr}
12300 & - & - \\
326 & - & - \\
322214 & - & - \\
18413 & - & - \\
6126 & - & - \\
101294 & - & - \\
45032 & - & - \\
167583 & 1009 & - \\
3076 & - & 100993 \\
24570 & 21597 & 138603 \\
46568 & 6142 & 2173 \\
\hline 747502 & 28748 & 251769 \\
\hline
\end{tabular}

\begin{tabular}{rrr}
757 & - & 486 \\
387 & - & 11 \\
61691 & -402 & 2428 \\
- & - & 4 \\
99062 & - & 1265 \\
- & 365 & -16 \\
1128 & - & 3 \\
33562 & - & 433 \\
1768 & - & - \\
- & - & 21 \\
2317 & - & 60 \\
\hline 200769 & -37 & 4695 \\
\hline
\end{tabular}

1559

$14658 \quad 189$

$171204 \quad 5262$

$\begin{array}{rr}51468 \\ 313 & 182888\end{array}$

$\begin{array}{rr}313 & 182888 \\ 7927 & 133126 \\ 9637 & 189036\end{array}$

$\begin{array}{lll}354 & 72866 & 608182\end{array}$

$\begin{array}{lll}- & 1044 & 115098\end{array}$

$2944 \quad 3292 \quad 106057$

$1 9 0 8 7 4 \longdiv { 1 1 2 5 1 8 } \overline { 2 6 0 6 4 7 0 }$

Notes for information

(1) Some of the industry/product group headings have been truncated

(2) Purchases of products by industry and by final consumption categories are valued at purchasers' prices.

NPISHs represents Non-Profit Institutions Serving Households.

GGFC represents General Government Final Consumption.

GFCF represents Gross Fixed Capital Formation.

Gross value added at basic prices plus taxes less subsidies on products gives GDP at market prices

Gross operating surplus includes gross mixed income.

Changes in inventories includes materials and fuels, work-in-progress and finished goods.

Valuables include both 'transfer costs' and 'acquisitions less disposals'. 


\begin{tabular}{|c|c|c|c|c|c|c|}
\hline \multirow{3}{*}{2005} & \multicolumn{6}{|c|}{ SUPPLY OF PRODUCTS } \\
\hline & \multirow{2}{*}{$\begin{array}{r}\text { Domestic } \\
\text { output of } \\
\text { products } \\
\text { at } \\
\text { basic prices }\end{array}$} & \multicolumn{2}{|c|}{ Imports } & \multirow{2}{*}{$\begin{array}{r}\text { Distributors' } \\
\text { trading } \\
\text { margins }\end{array}$} & \multirow{2}{*}{$\begin{array}{r}\text { Taxes } \\
\text { less } \\
\text { subsidies } \\
\text { on } \\
\text { products }\end{array}$} & \multirow{2}{*}{$\begin{array}{r}\text { Total } \\
\text { supply of } \\
\text { products at } \\
\text { purchasers' } \\
\text { prices }\end{array}$} \\
\hline & & Goods & Services & & & \\
\hline \multicolumn{7}{|l|}{ PRODUCTS ${ }^{1}$} \\
\hline Agriculture, forestry \& fishing [1-3] & 18349 & 6748 & 407 & 3845 & 653 & 30002 \\
\hline Mining \& quarrying $[4-7]$ & 39197 & 19883 & 480 & 1680 & 510 & 61750 \\
\hline Manufacturing [8-84] & 393201 & 250258 & 15558 & 216942 & 80286 & 956245 \\
\hline Electricity, gas \& water supply [85-87] & 59149 & 421 & 54 & - & 2079 & 61703 \\
\hline Construction [88] & 178514 & - & 636 & - & 12168 & 191318 \\
\hline Distribution \& hotels [89-92] & 333574 & - & 13986 & -222467 & 14384 & 139477 \\
\hline Transport \& communication [93-99] & 177848 & - & 20453 & - & 2777 & 201078 \\
\hline Finance \& business services $[100-114]$ & 592278 & 326 & 35033 & - & 15790 & 643427 \\
\hline Public administration \& defence [115] & 123193 & - & 44 & - & - & 123237 \\
\hline Education, health \& social work [116-118] & 243083 & - & 2001 & - & 2183 & 247267 \\
\hline Other services [119-123] & 98965 & 2561 & 4893 & - & 6554 & 112973 \\
\hline Total & 2257351 & 280197 & 93545 & - & 137384 & 2768477 \\
\hline \multicolumn{7}{|l|}{ of which: } \\
\hline Market output & 1861050 & & & & & \\
\hline Output for own final use & 97261 & & & & & \\
\hline Other non-market output & 299040 & & & & & \\
\hline
\end{tabular}

\section{Use Table at Purchasers' prices}

\begin{tabular}{|c|c|c|c|c|c|c|c|c|c|c|c|}
\hline \multirow[b]{2}{*}{2005} & \multicolumn{11}{|c|}{ INTERMEDIATE CONSUMPTION BY INDUSTRY GROUP ${ }^{12}$} \\
\hline & Agriculture & $\begin{array}{c}\text { Mining \& } \\
\text { quarrying }\end{array}$ & $\begin{array}{r}\text { Manufac- } \\
\text { turing }\end{array}$ & $\begin{array}{r}4 \\
\text { Electricity, } \\
\text { gas \& } \\
\text { water } \\
\text { supply }\end{array}$ & $\begin{array}{r}\text { Construc- } \\
\text { tion }\end{array}$ & $\begin{array}{r}6 \\
\text { Distribution } \\
\& \\
\text { hotels }\end{array}$ & $\begin{array}{r}7 \\
\text { Transport } \\
\& \\
\text { communi- } \\
\text { cation }\end{array}$ & $\begin{array}{r}8 \\
\text { Finance } \\
\& \\
\text { business } \\
\text { services }\end{array}$ & $\begin{array}{r}9 \\
\text { Public } \\
\text { adminis- } \\
\text { tration \& } \\
\text { defence }\end{array}$ & $\begin{array}{r}10 \\
\text { Education, } \\
\text { health \& } \\
\text { social work }\end{array}$ & $\begin{array}{r}\text { Other } \\
\text { services }\end{array}$ \\
\hline \multicolumn{12}{|l|}{ PRODUCTS ${ }^{1}$} \\
\hline Agriculture, forestry \& fishing [1-3] & 2315 & 1 & 10226 & 6 & 230 & 1677 & 42 & 12 & . & 221 & 32 \\
\hline Mining \& quarrying [4-7] & 6 & 4301 & 19940 & 16214 & 2996 & 158 & 121 & 10 & - & 6 & 24 \\
\hline Manufacturing [8-84] & 5947 & 2461 & 187493 & 3756 & 27718 & 45384 & 22926 & 12447 & 21866 & 29617 & 6920 \\
\hline Electricity, gas \& water supply [85-87] & 457 & 771 & 9675 & 19865 & 326 & 2514 & 1116 & 1800 & 1228 & 2140 & 717 \\
\hline Construction [88] & 243 & 748 & 1094 & 792 & 50979 & 1583 & 1816 & 12303 & 4811 & 998 & 841 \\
\hline Distribution \& hotels [89-92] & 684 & 127 & 1155 & 173 & 1813 & 7826 & 3502 & 6045 & 1762 & 2167 & 760 \\
\hline Transport \& communication [93-99] & 422 & 1345 & 14175 & 583 & 1233 & 32921 & 39543 & 27724 & 4997 & 5745 & 2792 \\
\hline Finance \& business services $[100-114]$ & 2127 & 3230 & 31609 & 3944 & 21945 & 55379 & 27368 & 145396 & 20039 & 21974 & 18023 \\
\hline Public administration \& defence [115] & 12 & 22 & 550 & 38 & 383 & 247 & 1859 & 6777 & 266 & 90 & 77 \\
\hline Education, health \& social work [116-118] & 186 & 36 & 1135 & 203 & 168 & 909 & 1241 & 5156 & 4627 & 32429 & 942 \\
\hline Other services [119-123] & 221 & 110 & 3015 & 216 & 169 & 1953 & 1868 & 3842 & 3501 & 3696 & 15868 \\
\hline Total consumption & 12620 & 13152 & 280067 & 45790 & 107960 & 150551 & 101402 & 221512 & 63097 & 99083 & 46996 \\
\hline Taxes less subsidies on production & -3252 & 241 & 2384 & 1248 & 624 & 8386 & 1165 & 1917 & - & 180 & 956 \\
\hline Compensation of employees & 3653 & 3330 & 106616 & 5049 & 33409 & 102301 & 54942 & 156326 & 51799 & 125913 & 38867 \\
\hline Gross operating surplus & 7021 & 24098 & 39591 & 10370 & 33986 & 52234 & 24403 & 180448 & 8297 & 18590 & 20029 \\
\hline Gross value added at basic prices & 7422 & 27669 & 148591 & 16667 & 68019 & 162921 & 80510 & 338691 & 60096 & 144683 & 59852 \\
\hline Output at basic prices & 20042 & 40821 & 428658 & 62457 & 175979 & 313472 & 181912 & 560203 & 123193 & 243766 & 106848 \\
\hline
\end{tabular}




\section{Gross value added at basic prices}

f billion

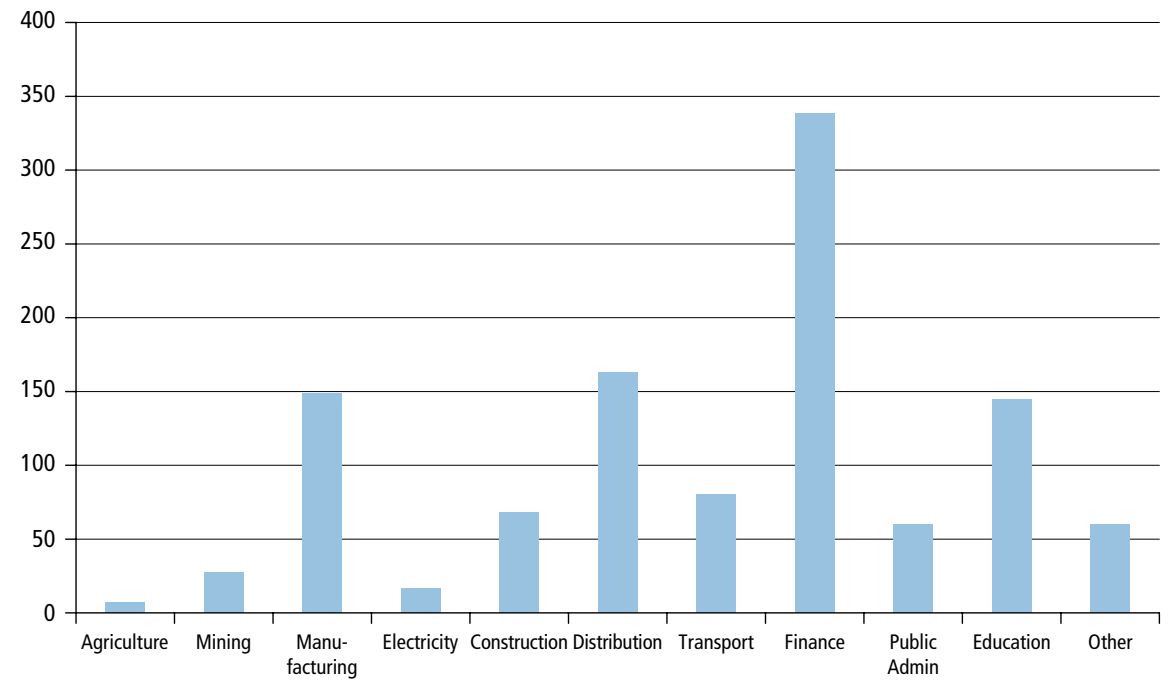

\section{Components of final demand}

Per cent

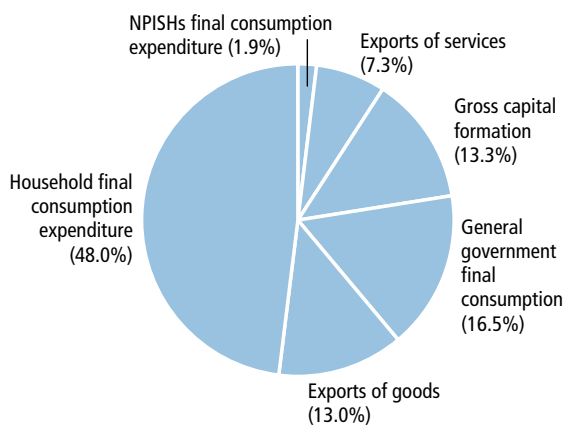

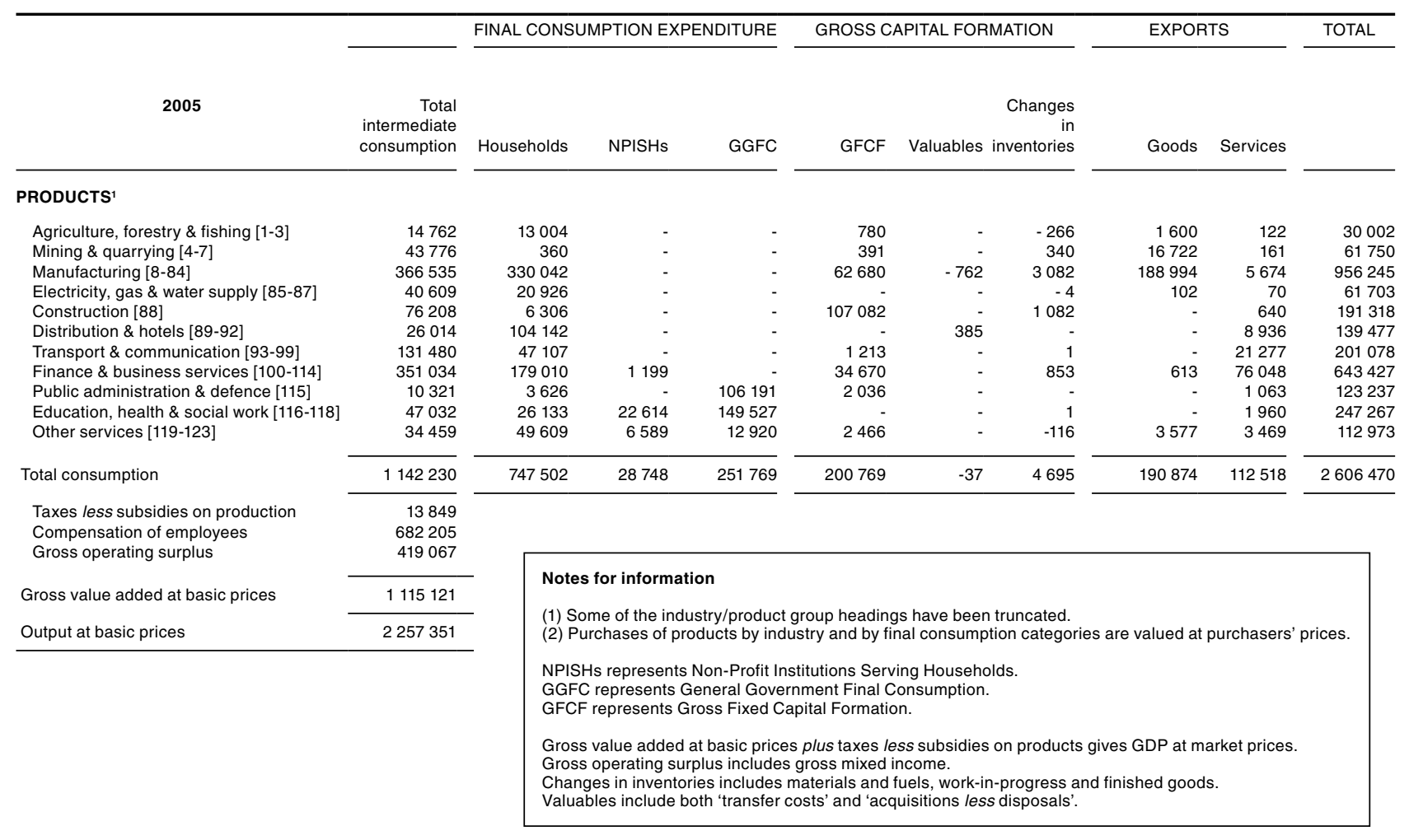




\begin{tabular}{|c|c|c|c|c|c|c|}
\hline \multirow{3}{*}{2006} & \multicolumn{6}{|c|}{ SUPPLY OF PRODUCTS } \\
\hline & \multirow{2}{*}{$\begin{array}{r}\text { Domestic } \\
\text { output of } \\
\text { products } \\
\text { at } \\
\text { basic prices }\end{array}$} & \multicolumn{2}{|c|}{ Imports } & \multirow{2}{*}{$\begin{array}{r}\text { Distributors' } \\
\text { trading } \\
\text { margins }\end{array}$} & \multirow{2}{*}{$\begin{array}{r}\text { Taxes } \\
\text { less } \\
\text { subsidies } \\
\text { on } \\
\text { products }\end{array}$} & \multirow{2}{*}{$\begin{array}{r}\text { Total } \\
\text { supply of } \\
\text { products at } \\
\text { purchasers' } \\
\text { prices }\end{array}$} \\
\hline & & Goods & Services & & & \\
\hline \multicolumn{7}{|l|}{ PRODUCTS ${ }^{1}$} \\
\hline Agriculture, forestry \& fishing [1-3] & 19172 & 7173 & 421 & 3909 & 632 & 31307 \\
\hline Mining \& quarrying $[4-7]$ & 45351 & 24218 & 543 & 1760 & 545 & 72417 \\
\hline Manufacturing [8-84] & 412610 & 284924 & 16168 & 224165 & 84881 & 1022748 \\
\hline Electricity, gas \& water supply [85-87] & 69567 & 399 & 63 & - & 2148 & 72177 \\
\hline Construction [88] & 189007 & - & 692 & - & 12948 & 202647 \\
\hline Distribution \& hotels [89-92] & 345519 & - & 14425 & -229834 & 15134 & 145244 \\
\hline Transport \& communication [93-99] & 183218 & - & 20534 & - & 2399 & 206151 \\
\hline Finance \& business services $[100-114]$ & 628641 & 298 & 39799 & - & 16682 & 685420 \\
\hline Public administration \& defence [115] & 129377 & - & 61 & - & - & 129438 \\
\hline Education, health \& social work [116-118] & 259119 & - & 1979 & - & 2318 & 263416 \\
\hline Other services [119-123] & 103246 & 2935 & 4956 & - & 6941 & 118078 \\
\hline Total & 2384827 & 319947 & 99641 & - & 144628 & 2949043 \\
\hline \multicolumn{7}{|l|}{ of which: } \\
\hline Market output & 1963066 & & & & & \\
\hline Output for own final use & 103883 & & & & & \\
\hline Other non-market output & 317878 & & & & & \\
\hline
\end{tabular}

\section{Use Table at Purchasers' prices}

\begin{tabular}{|c|c|c|c|c|c|c|c|c|c|c|c|}
\hline \multirow[b]{2}{*}{2006} & \multicolumn{11}{|c|}{ INTERMEDIATE CONSUMPTION BY INDUSTRY GROUP ${ }^{12}$} \\
\hline & Agriculture & $\begin{array}{c}\text { Mining \& } \\
\text { quarrying }\end{array}$ & $\begin{array}{r}\text { Manufac- } \\
\text { turing }\end{array}$ & $\begin{array}{r}4 \\
\text { Electricity, } \\
\text { gas \& } \\
\text { water } \\
\text { supply }\end{array}$ & $\begin{array}{r}\text { Construc- } \\
\text { tion }\end{array}$ & $\begin{array}{r}6 \\
\text { Distribution } \\
\& \\
\text { hotels }\end{array}$ & $\begin{array}{r}7 \\
\text { Transport } \\
\& \\
\text { communi- } \\
\text { cation }\end{array}$ & $\begin{array}{r}8 \\
\text { Finance } \\
\& \\
\text { business } \\
\text { services }\end{array}$ & $\begin{array}{r}9 \\
\text { Public } \\
\text { adminis- } \\
\text { tration \& } \\
\text { defence }\end{array}$ & $\begin{array}{r}10 \\
\text { Education, } \\
\text { health \& } \\
\text { social work }\end{array}$ & $\begin{array}{r}\text { Other } \\
\text { services }\end{array}$ \\
\hline \multicolumn{12}{|l|}{ PRODUCTS' } \\
\hline Agriculture, forestry \& fishing [1-3] & 2495 & 1 & 10520 & 6 & 240 & 1678 & 42 & 12 & 2 & 223 & 34 \\
\hline Mining \& quarrying [4-7] & 10 & 5172 & 23743 & 19802 & 3271 & 169 & 124 & 12 & - & 9 & 28 \\
\hline Manufacturing $[8-84]$ & 6206 & 2530 & 196391 & 4068 & 29694 & 46955 & 25508 & 13661 & 23472 & 32899 & 7635 \\
\hline Electricity, gas \& water supply [85-87] & 423 & 779 & 9928 & 24061 & 344 & 2675 & 1151 & 1906 & 1321 & 2453 & 838 \\
\hline Construction [88] & 243 & 872 & 1128 & 839 & 51437 & 1451 & 1880 & 12433 & 4954 & 1076 & 869 \\
\hline Distribution \& hotels [89-92] & 693 & 146 & 1201 & 193 & 2172 & 8781 & 4097 & 6713 & 1826 & 2589 & 890 \\
\hline Transport \& communication [93-99] & 440 & 1431 & 14733 & 611 & 1273 & 33905 & 40256 & 29240 & 5173 & 5967 & 2885 \\
\hline Finance \& business services [100-114] & 2145 & 3504 & 32454 & 4213 & 23087 & 57006 & 28224 & 150358 & 21096 & 24046 & 19215 \\
\hline Public administration \& defence [115] & 12 & 25 & 540 & 41 & 439 & 283 & 2019 & 7037 & 292 & 109 & 94 \\
\hline Education, health \& social work [116-118] & 188 & 40 & 1160 & 218 & 166 & 894 & 1257 & 5490 & 4825 & 35038 & 979 \\
\hline Other services [119-123] & 233 & 117 & 3194 & 233 & 183 & 2048 & 2012 & 4114 & 3383 & 4089 & 16607 \\
\hline Total consumption & 13088 & 14617 & 294992 & 54285 & 112306 & 155845 & 106570 & 230976 & 66344 & 108498 & 50074 \\
\hline Taxes less subsidies on production & -3088 & 284 & 2464 & 1256 & 678 & 8747 & 1058 & 1893 & - & 201 & 1025 \\
\hline Compensation of employees & 3551 & 3122 & 108830 & 6142 & 36031 & 105609 & 57303 & 168893 & 54246 & 131680 & 40089 \\
\hline Gross operating surplus & 7402 & 28796 & 41861 & 11472 & 37284 & 55480 & 22666 & 193869 & 8787 & 19347 & 20254 \\
\hline Gross value added at basic prices & 7865 & 32202 & 153155 & 18870 & 73993 & 169836 & 81027 & 364655 & 63033 & 151228 & 61368 \\
\hline Output at basic prices & 20953 & 46819 & 448147 & 73155 & 186299 & 325681 & 187597 & 595631 & 129377 & 259726 & 111442 \\
\hline
\end{tabular}




\section{Gross value added at basic prices}

f billion

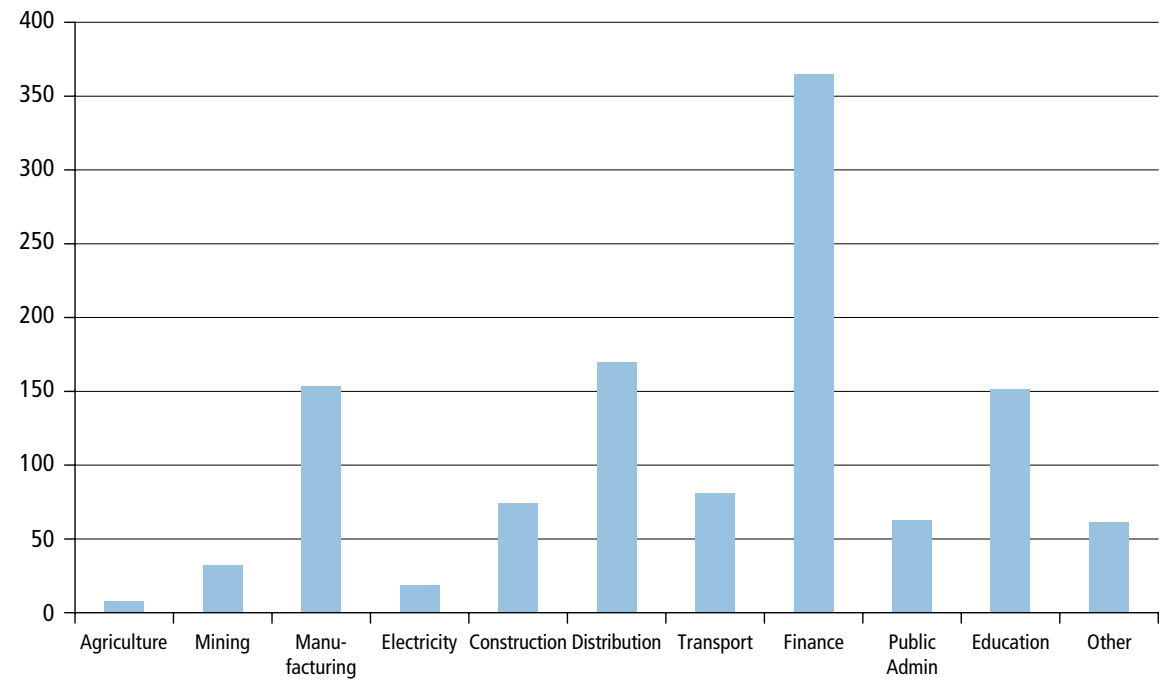

\section{Components of final demand}

Per cent

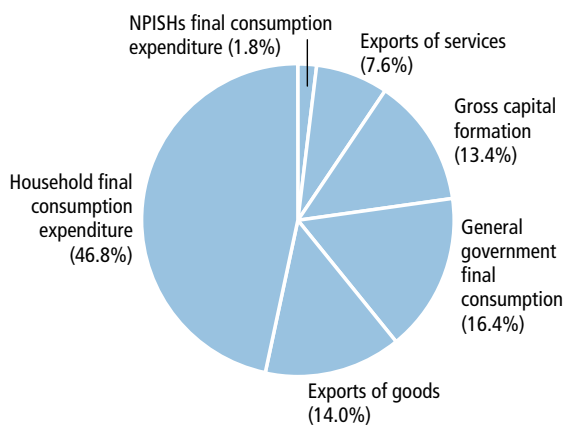

FINAL CONSUMPTION EXPENDITURE GROSS CAPITAL FORMATION

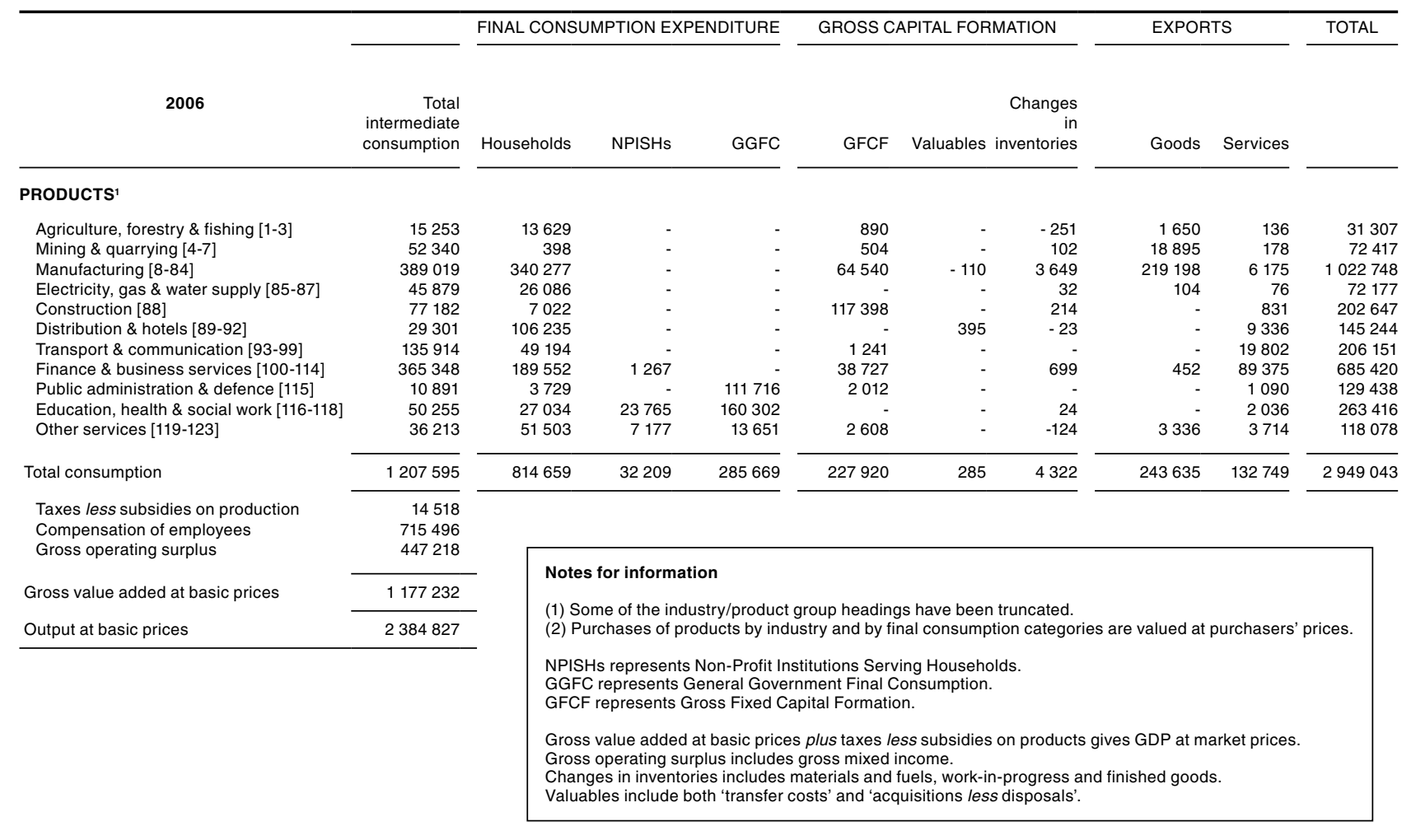

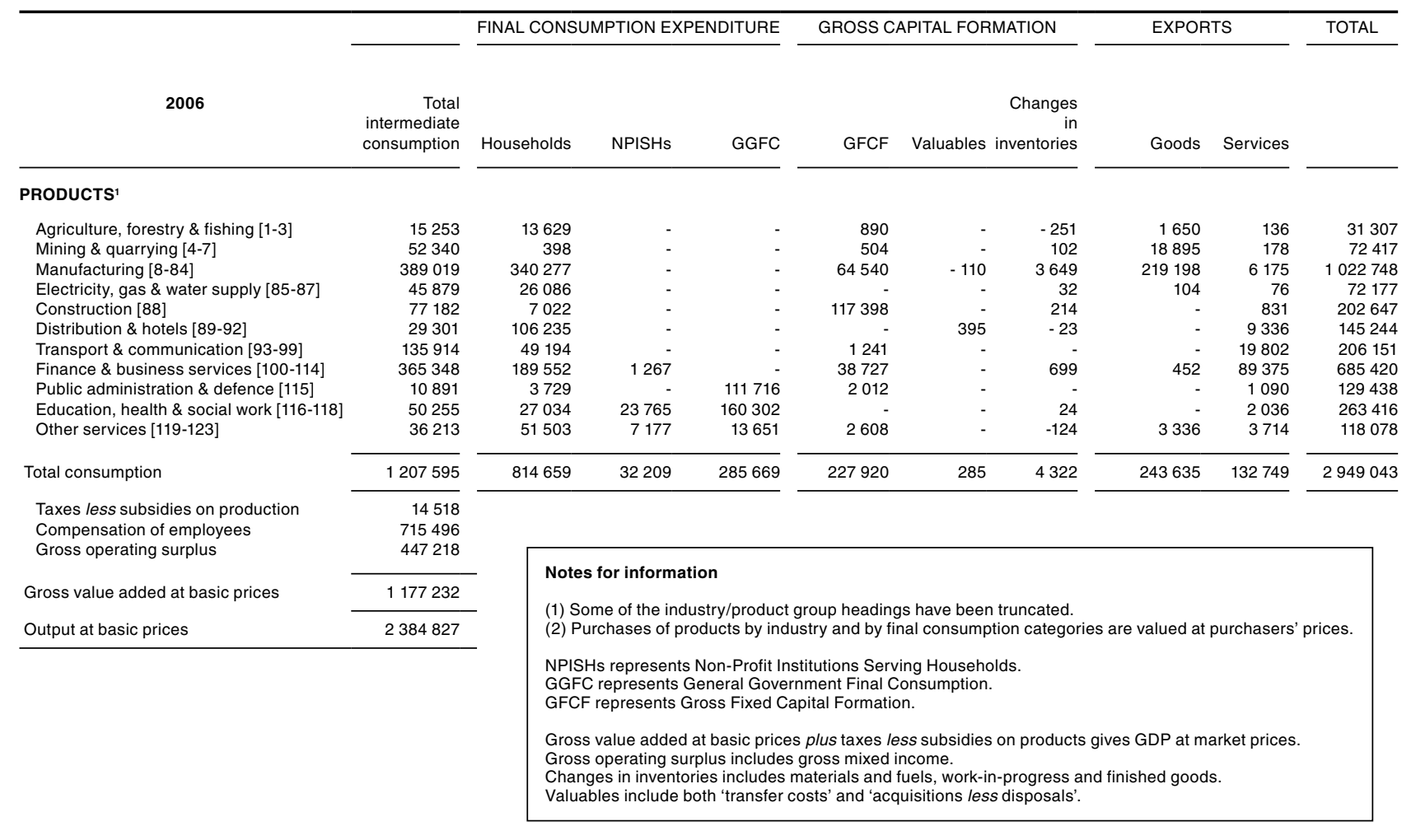




\section{Output and capital formation: by industry ${ }^{1,2}$ 2. 2 Gross value added at current basic prices}

\begin{tabular}{|c|c|c|c|c|c|c|c|c|c|c|}
\hline & & & & & & & & & & $\mathrm{f}$ million \\
\hline & & & 1999 & 2000 & 2001 & 2002 & 2003 & 2004 & 2005 & 2006 \\
\hline & Agriculture, hunting, forestry and fishing & & & & & & & & & \\
\hline P.1 & Output & & & & & & & & & \\
\hline $\begin{array}{ll}\text { D.1 } \\
\text { D.29-D.39 }\end{array}$ & $\begin{array}{l}\text { Compensation of employees } \\
\text { Taxes less subsidies on production other than }\end{array}$ & CFHE & 3249 & 3243 & 3245 & 3225 & 3286 & 3454 & 3653 & 3551 \\
\hline B. $2 \mathrm{~g} / \mathrm{B} .3 \mathrm{~g}$ & $\begin{array}{l}\text { those on products } \\
\text { Operating surplus/Mixed income, gross }\end{array}$ & $\begin{array}{l}\text { EWTZ } \\
\text { ESMU }\end{array}$ & $\begin{array}{r}-155 \\
5928\end{array}$ & $\begin{array}{r}-169 \\
5458\end{array}$ & $\begin{array}{r}-429 \\
5517\end{array}$ & $\begin{array}{r}-348 \\
6130\end{array}$ & $\begin{array}{r}-397 \\
6917\end{array}$ & $\begin{array}{r}-446 \\
7592\end{array}$ & $\begin{array}{r}-3252 \\
7021\end{array}$ & $\begin{array}{r}-3088 \\
7402\end{array}$ \\
\hline $\begin{array}{l}\text { B. } 1 \mathrm{~g} \\
\text { P.2 }\end{array}$ & $\begin{array}{l}\text { Gross value added at basic prices } \\
\text { Intermediate consumption at purchasers' prices }\end{array}$ & $\begin{array}{l}\text { QTOP } \\
\text { EWSI }\end{array}$ & $\begin{array}{r}9022 \\
12349\end{array}$ & $\begin{array}{r}8532 \\
11955\end{array}$ & $\begin{array}{r}8333 \\
11335\end{array}$ & $\begin{array}{r}9007 \\
11374\end{array}$ & $\begin{array}{r}9806 \\
11782\end{array}$ & $\begin{array}{l}10600 \\
12373\end{array}$ & $\begin{array}{r}7422 \\
12620\end{array}$ & $\begin{array}{r}7865 \\
13088\end{array}$ \\
\hline P.1 & Total output at basic prices & EWSJ & 21371 & 20487 & 19668 & 20381 & 21588 & 22973 & 20042 & 20953 \\
\hline P.5 & Gross capital formation & EWSK & 1960 & 1874 & 2083 & 2675 & 2879 & 2664 & 2751 & 3001 \\
\hline & Mining and quarrying & & & & & & & & & \\
\hline P.1 & Output & & & & & & & & & \\
\hline $\begin{array}{l}\text { D. } 1 \\
\text { D.29-D.39 }\end{array}$ & $\begin{array}{l}\text { Compensation of employees } \\
\text { Taxes less subsidies on production other than }\end{array}$ & CFHF & 2808 & 3003 & 2945 & 2856 & 2834 & 3105 & 3330 & 3122 \\
\hline B. $2 \mathrm{~g} / \mathrm{B} .3 \mathrm{~g}$ & $\begin{array}{l}\text { those on products } \\
\text { Operating surplus/Mixed income, gross }\end{array}$ & $\begin{array}{l}\text { EWUA } \\
\text { ESMQ }\end{array}$ & $\begin{array}{r}161 \\
13976\end{array}$ & $\begin{array}{r}171 \\
21391\end{array}$ & $\begin{array}{r}222 \\
19953\end{array}$ & $\begin{array}{r}143 \\
18919\end{array}$ & $\begin{array}{r}123 \\
18485\end{array}$ & $\begin{array}{r}187 \\
19268\end{array}$ & $\begin{array}{r}241 \\
24098\end{array}$ & $\begin{array}{r}284 \\
28796\end{array}$ \\
\hline $\begin{array}{l}\text { B. } 1 \mathrm{~g} \\
\text { P.2 }\end{array}$ & $\begin{array}{l}\text { Gross value added at basic prices } \\
\text { Intermediate consumption at purchasers' prices }\end{array}$ & $\begin{array}{l}\text { QTOT } \\
\text { EWSM }\end{array}$ & $\begin{array}{r}16945 \\
9199\end{array}$ & $\begin{array}{l}24565 \\
10096\end{array}$ & $\begin{array}{l}23120 \\
10340\end{array}$ & $\begin{array}{r}21918 \\
9749\end{array}$ & $\begin{array}{l}21442 \\
10219\end{array}$ & $\begin{array}{l}22560 \\
11295\end{array}$ & $\begin{array}{l}27669 \\
13152\end{array}$ & $\begin{array}{l}32202 \\
14617\end{array}$ \\
\hline P.1 & Total output at basic prices & EWSN & 26144 & 34661 & 33460 & 31667 & 31661 & 33855 & 40821 & 46819 \\
\hline P.5 & Gross capital formation & EWSO & 4830 & 3384 & 4568 & 5201 & 4621 & 4344 & 4241 & 4735 \\
\hline & Manufacturing $^{3}$ & & & & & & & & & \\
\hline B. $2 \mathrm{~g} / \mathrm{B} . \mathrm{g}$ & $\begin{array}{l}\text { those on products } \\
\text { Operating surplus/Mixed income, gross }\end{array}$ & $\begin{array}{l}\text { EWUB } \\
\text { ESMT }\end{array}$ & $\begin{array}{r}2578 \\
45872\end{array}$ & $\begin{array}{r}2573 \\
42701\end{array}$ & $\begin{array}{r}2642 \\
42200\end{array}$ & $\begin{array}{r}2690 \\
39527\end{array}$ & $\begin{array}{r}2588 \\
38455\end{array}$ & $\begin{array}{r}2451 \\
40550\end{array}$ & $\begin{array}{r}2384 \\
39591\end{array}$ & $\begin{array}{r}2464 \\
41861\end{array}$ \\
\hline B. $1 \mathrm{~g}$ & Gross value added at basic prices & QTPI & 151157 & 150009 & 149223 & 146308 & 144845 & 147261 & 148591 & 153155 \\
\hline P.2 & Intermediate consumption at purchasers' prices & EWSQ & 254175 & 264591 & 262690 & 259319 & 259646 & 265843 & 280067 & 294992 \\
\hline P.1 & Total output at basic prices & EWSR & 405332 & 414600 & 411913 & 405627 & 404491 & 413104 & 428658 & 448147 \\
\hline P.5 & Gross capital formation & EWSS & 19596 & 20735 & 17805 & 14084 & 13726 & 13604 & 15839 & 15756 \\
\hline
\end{tabular}

1 The contribution of each industry to the gross domestic product before providing for consumption of fixed capital. The industrial composition in this table is consistent with the Input-Output Supply and Use Tables in Table 2.1, which show data from 2004-2006

2 Components may not sum to totals due to rounding.

3 Further detail is given in Table 2.3. 


\section{Output and capital formation: by industry ${ }^{1,2}$ 2. 2 Gross value added at current basic prices}

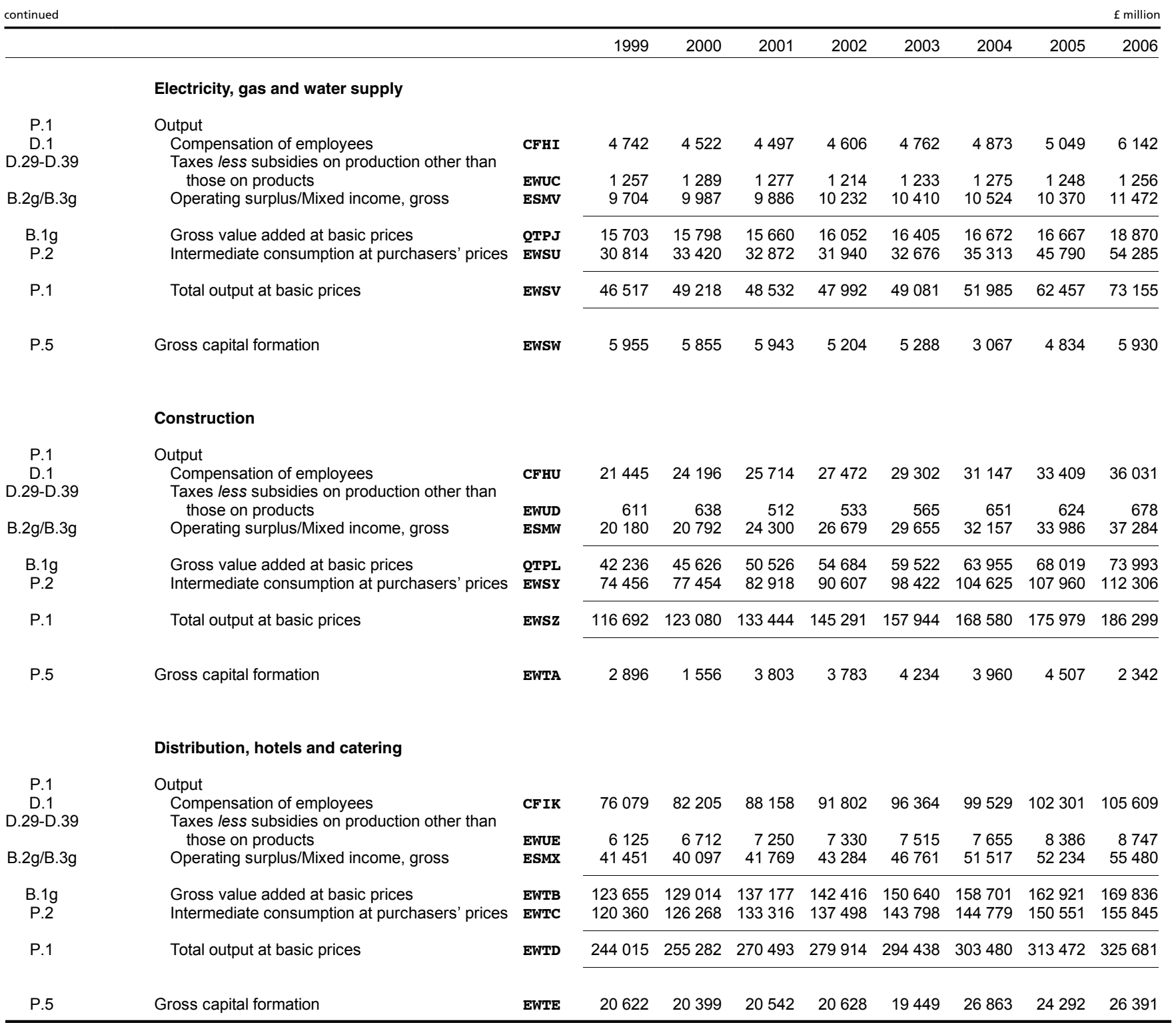

See footnotes on first page of this table. 


\section{Output and capital formation: by industry ${ }^{1,2}$ 2. 2 Gross value added at current basic prices}

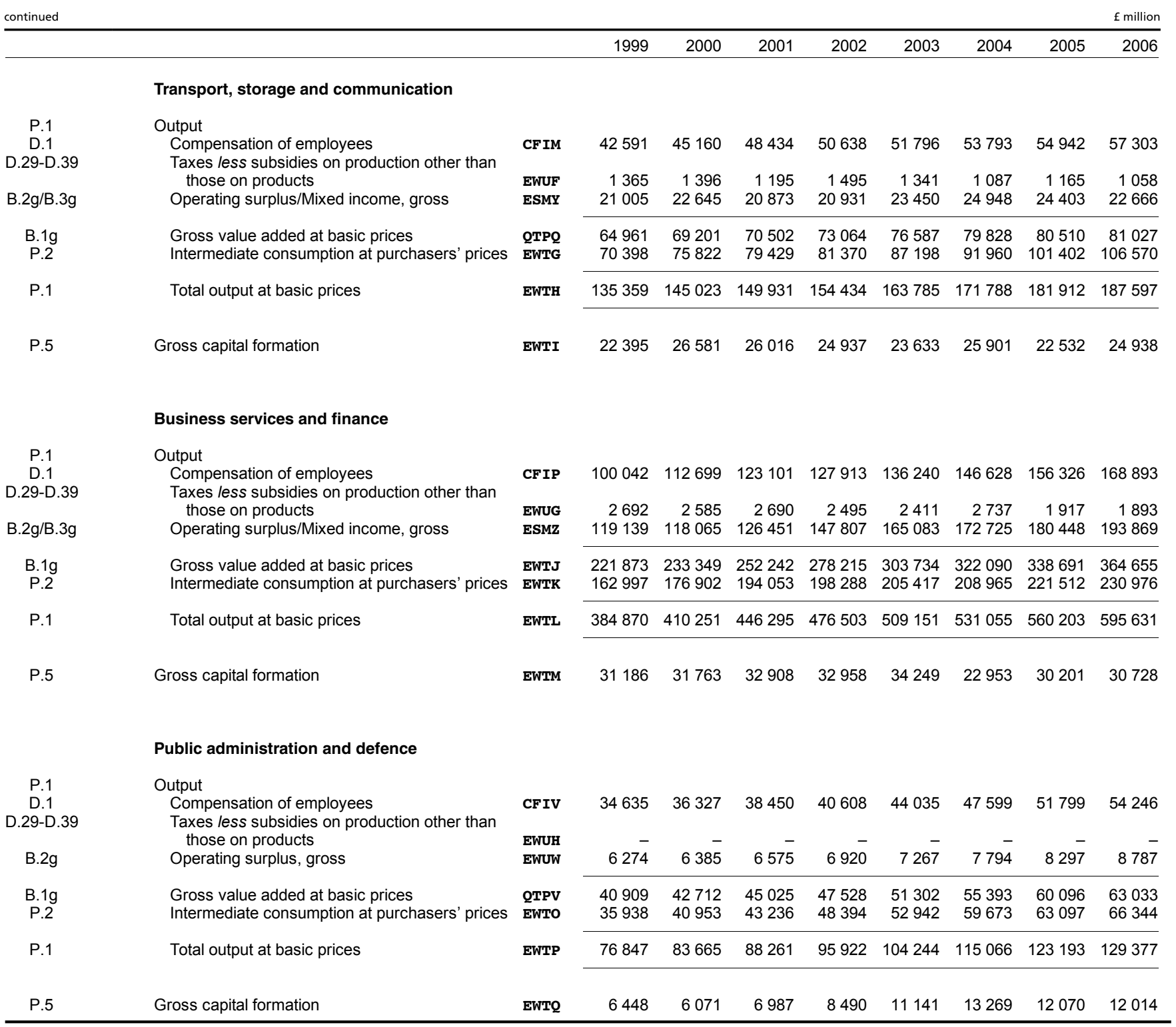

See footnotes on first page of this table. 


\section{Output and capital formation: by industry ${ }^{1,2}$ - . Gross value added at current basic prices}

\begin{tabular}{|c|c|c|c|c|c|c|c|c|c|c|}
\hline & & & 1999 & 2000 & 2001 & 2002 & 2003 & 2004 & 2005 & 2006 \\
\hline & Education, health and social work & & & & & & & & & \\
\hline P.1 & Output & & & & & & & & & \\
\hline D. 1 & Compensation of employees & CFIW & 83574 & 89797 & 96724 & 103787 & 112124 & 119073 & 125913 & 131680 \\
\hline D.29-D.39 & $\begin{array}{l}\text { Taxes less subsidies on production other } \\
\text { than those on products }\end{array}$ & EWUI & 144 & 162 & 130 & 190 & 152 & 152 & 180 & \\
\hline B. $2 \mathrm{~g} / \mathrm{B} .3 \mathrm{~g}$ & Operating surplus/Mixed income, gross & EWSF & 12773 & 13434 & 14370 & 15614 & 16645 & 17006 & 18590 & 19347 \\
\hline \multirow{2}{*}{$\begin{array}{l}\text { B.1g } \\
\text { P.2 }\end{array}$} & Gross value added at basic prices & EWTR & 96491 & 103393 & 111224 & 119591 & 128921 & 136231 & 144683 & 151228 \\
\hline & purchasers' prices & EWTS & 57491 & 61007 & 66240 & 73261 & 80745 & 90113 & 99083 & 108498 \\
\hline P.1 & Total output at basic prices & EWTT & 153982 & 164400 & 177464 & 192852 & 209666 & 226344 & 243766 & 259726 \\
\hline P.5 & Gross capital formation & EWTU & 7026 & 6891 & 8119 & 8630 & 9447 & 10667 & 11961 & 13294 \\
\hline
\end{tabular}

\section{Other services}

P.1 Output

D.1

D.29-D.39

B. $2 \mathrm{~g} / \mathrm{B} .3 \mathrm{~g}$

$\begin{array}{ll}\text { B.1g } & \begin{array}{c}\text { Gross value added at basic prices } \\ \text { P.2 }\end{array} \\ \text { P.1 } & \begin{array}{c}\text { purchasers' prices } \\ \text { P. }\end{array} \\ \text { P.5 } & \text { Total output at basic prices }\end{array}$

Compensation of employees

Taxes less subsidies on produc

than those on products

Operating surplus/Mixed income, gross

Gross value added at basic prices termediate consumption at

\section{Not allocated to industries}

\section{All industries}

\begin{tabular}{|c|c|}
\hline P.1 & Output \\
\hline D.1 & Compensation of employees \\
\hline $.29-D .39$ & $\begin{array}{l}\text { Taxes less subsidies on production other } \\
\text { than those on products }\end{array}$ \\
\hline B. $2 \mathrm{~g}$ & Operating surplus, gross \\
\hline B. $3 g$ & Mixed income, gross \\
\hline $\mathrm{di}$ & $\begin{array}{l}\text { Statistical discrepancy between income } \\
\text { and GDP }\end{array}$ \\
\hline B. $1 \mathrm{~g}$ & Gross value added at basic prices \\
\hline P.2 & $\begin{array}{l}\text { Intermediate consumption at } \\
\text { purchasers' prices }\end{array}$ \\
\hline P.1 & Total output at basic prices \\
\hline P.5 & Gross capital formation \\
\hline P.51 & Gross fixed capital formation \\
\hline P.52 & Changes in inventories \\
\hline P.53 & Acquisitions less disposals of valuables \\
\hline P.5 & Total gross capital formation \\
\hline
\end{tabular}

\begin{tabular}{|c|c|c|c|c|c|c|c|c|}
\hline HAEA & 495793 & 532179 & 564194 & 587396 & 616893 & 648099 & 682205 & 715496 \\
\hline QZPC & 15502 & 16174 & 16321 & 16640 & 16491 & 16699 & 13849 & 14518 \\
\hline ABNF & 256537 & 259001 & 265797 & 288091 & 313300 & 330960 & 344209 & 368310 \\
\hline QWLT & 54942 & 56931 & 61282 & 64967 & 68324 & 72816 & 74858 & 78908 \\
\hline RVFC & - & - & - & - & - & - & - & - \\
\hline ABML & 822774 & 864285 & 907594 & 957094 & 1015008 & 1068574 & 1115121 & 1177232 \\
\hline NQAJ & 861014 & 913075 & 953417 & 982440 & 1025167 & 1069729 & 1142230 & 1207595 \\
\hline NQAF & 1683788 & 1777360 & 1861011 & 1939534 & 2040175 & 2138303 & 2257351 & 2384827 \\
\hline NPQX & 161722 & 167172 & 171782 & 180551 & 186700 & 200672 & 211318 & 227920 \\
\hline ABMP & 6060 & 5271 & 6189 & 2909 & 3983 & 4695 & 4973 & 4322 \\
\hline NPJO & 229 & 3 & 396 & 214 & -37 & -37 & -377 & 285 \\
\hline NQFM & 168011 & 172446 & 178367 & 183674 & 190646 & 205330 & 215914 & 232527 \\
\hline
\end{tabular}




\section{3 Gross value added at current basic prices: by industry ${ }^{1,2}$}

\begin{tabular}{|c|c|c|c|c|c|c|c|c|c|c|c|}
\hline & & & 1999 & 2000 & 2001 & 2002 & 2003 & 2004 & 2005 & 2006 & 2007 \\
\hline$A, B$ & Agriculture, hunting, forestry and fishing & QTOP & 9022 & 8532 & 8333 & 9007 & 9806 & 10600 & 7422 & 7865 & 8910 \\
\hline \multicolumn{12}{|c|}{$C, D, E$ Production } \\
\hline $\begin{array}{c}\mathrm{C} \\
\mathrm{CA}\end{array}$ & $\begin{array}{l}\text { Mining and quarrying } \\
\text { Mining and quarrying of energy producing materials }\end{array}$ & & & & & & & & & & \\
\hline C10 & Mining of coal & QтоQ & 639 & 607 & 545 & 538 & 472 & 398 & 323 & 314 & \\
\hline C11 & Extraction of mineral oil and natural gas & QTOR & 14606 & 22174 & 20825 & 19911 & 19451 & 20321 & 25265 & 29776 & 2983 \\
\hline $\mathrm{CB}$ & Other mining and quarrying & QтоS & 1700 & 1784 & 1750 & 1469 & 1519 & 1841 & 2081 & 2112 & 2291 \\
\hline C & Total mining and quarrying & Qтот & 16945 & 24565 & 23120 & 21918 & 21442 & 22560 & 27669 & 32202 & 32431 \\
\hline D & Manufacturing & & & & & & & & & & \\
\hline $\mathrm{DA}$ & Food; beverages and tobacco & QтоU & 19953 & 19963 & 20655 & 20834 & 21408 & 21979 & 21826 & 22143 & 22996 \\
\hline DB & Textiles and textile products & QTOV & 6220 & 5813 & 5343 & 4818 & 4282 & 4240 & 3977 & 3944 & 3887 \\
\hline $\mathrm{DC}$ & d leather products & QтоW & 803 & 747 & 645 & 590 & 462 & 474 & 424 & 418 & 4 \\
\hline $\mathrm{DD}$ & Wood and wood products & Qтох & 2204 & 2294 & 2332 & 2479 & 2655 & 2790 & 3052 & 3200 & 3603 \\
\hline $\mathrm{DE}$ & Pulp, paper and paper products; publishing and printing & QTOY & 19558 & 20187 & 20129 & 20008 & 19780 & 19378 & 19315 & 19246 & 19530 \\
\hline $\mathrm{DF}$ & oducts and nuclear fuel & QTOZ & 2533 & 2336 & 2488 & 2435 & 2377 & 2439 & 2529 & 2506 & 2636 \\
\hline $\mathrm{DG}$ & Chemicals, chemical products and man-made fibres & QTPA & 15165 & 15040 & 16077 & 16083 & 16149 & 17321 & 17246 & 18847 & 18874 \\
\hline $\mathrm{DH}$ & Rubber and plastic products & QTPB & 7708 & 7609 & 7656 & 7569 & 7516 & 7380 & 7563 & 7928 & 79 \\
\hline $\mathrm{DI}$ & ral products & QTPC & 4908 & 4965 & 5033 & 5296 & 5417 & 5528 & 5193 & 5469 & 5718 \\
\hline DJ & Basic metals and fabricated metal products & QTPD & 16580 & 15903 & 15525 & 14897 & 14774 & 15678 & 16402 & 16400 & 17312 \\
\hline DK & Machinery and equipment not elsewhere classified & QTPE & 12726 & 12346 & 12256 & 12085 & 12146 & 12381 & 12525 & 13901 & 148 \\
\hline $\mathrm{DL}$ & Electrical and optical equipment & QTPF & 20331 & 20337 & 18347 & 16468 & 15545 & 15661 & 16117 & 15908 & 15730 \\
\hline DM & Transport equipment & QTPG & 16113 & 15987 & 16091 & 16178 & 15903 & 15652 & 15932 & 16305 & 16805 \\
\hline DN & Manufacturing not elsewhere classified & QTPH & 6354 & 6477 & 6643 & 6567 & 6429 & 6361 & 6491 & 6938 & 7403 \\
\hline D & Total manufacturing & QTPI & 151157 & 150009 & 149223 & 146308 & 144845 & 147261 & 148591 & 153155 & 157728 \\
\hline$E$ & Electricity, gas and water supply & QTPJ & 15703 & 15798 & 15660 & 16052 & 16405 & 16672 & 16667 & 18870 & 18696 \\
\hline $\mathrm{C}, \mathrm{D}, \mathrm{E}$ & Total production & QTPK & 183803 & 1903671 & 188000 & 184277 & 182690 & 186494 & 192928 & 204225 & 208855 \\
\hline $\mathrm{F}$ & Construction & QTPL & 42236 & 45626 & 50526 & 54684 & 59522 & 63955 & 68019 & 73993 & \\
\hline
\end{tabular}

\section{G-Q Service industries}

G Wholesale and retail trade (including motor trade); repair of motor vehicles, personal and household goods QTPM $99510103409110250113778 \quad 120520127411 \quad 130952136071 \quad 142402$

$\mathrm{H} \quad$ Hotels and restaurants

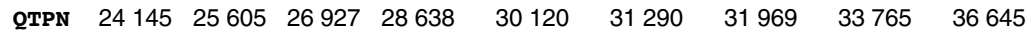

I Transport, storage and communication Transport and storage Communication

$\begin{array}{llllllllll}\text { QTPO } & 40973 & 42476 & 43184 & 44501 & 47022 & 49576 & 50203 & 50491 & 53434\end{array}$

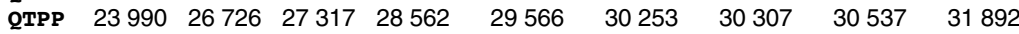

I Total

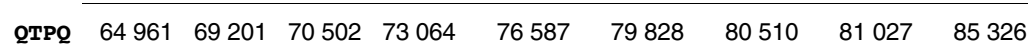

$\mathrm{J} \quad$ Financial intermediation

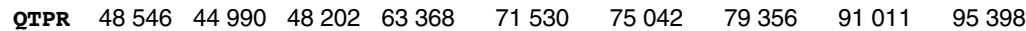

K Real estate, renting and business activities Letting of dwellings including imputed rent of owner occupiers

Other real estate, renting and business activities

$\begin{array}{llllllllll}\text { QTPS } & 53502 & 57261 & 61352 & 64249 & 69298 & 76166 & 80155 & 84809 & 90065\end{array}$ $\begin{array}{llllllll}\text { QTPT } & 119825131098142688150598 & 162906 & 170882 & 179180 & 188835 & 212540\end{array}$ QTPU $173327188359204040214847 \quad 232204 \quad 247048 \quad 259335 \quad 273644 \quad 302605$

K Total

$\mathrm{L} \quad$ Public administration and defence (PAD)

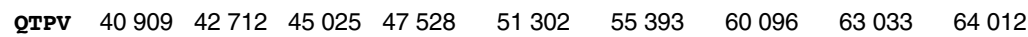

M Education

$\mathrm{N} \quad$ Health and social work $\begin{array}{llllllllll}\text { QTPW } & 44914 & 48111 & 51675 & 55099 & 58328 & 61814 & 66186 & 69345 & 73105\end{array}$ $\begin{array}{llllllllll}\text { QTPX } & 51577 & 55282 & 59549 & 64492 & 70593 & 74417 & 78497 & 81883 & 86689\end{array}$

$\mathrm{O}, \mathrm{P}, \mathrm{Q}$ Other social and personal services, private households with employees and extra-territorial organisations

$\begin{array}{llllllllll}\text { QTPY } & 39822 & 42086 & 44561 & 48312 & 51804 & 55283 & 59852 & 61368 & 64151\end{array}$ QTPZ $587715619756660729709122 \quad 762988 \quad 807529 \quad 846753 \quad 891148 \quad 950333$

G-Q Total service industries

1 Components may not sum to totals as a result of rounding.

2 Because of differences in the annual and monthly production inquiries, estimates of current price output and gross value added by industry derived from the current price Input-Output Supply and Use Tables are not consistent with the equivalent measures of chained volume measures growth given in 2.4. These differences do not affect GDP totals. 


\section{Gross value added at basic prices: by industry ${ }^{1,2,3}$ \\ Chained volume indices}

Indices $2003=100$

\begin{tabular}{cl}
\hline & \\
& \\
& \\
A,B & Agriculture, hunting, forestry and fishing \\
& \\
C,D,E & Production \\
C & Mining and quarrying \\
CA & Mining and quarrying of energy producing materials \\
C10 & Mining of coal \\
C11 & Extraction of mineral oil and natural gas \\
CB & Other mining and quarrying \\
& Total mining and quarrying \\
C & \\
& \\
D & Manufacturing \\
DA & Food; beverages and tobacco \\
DB & Textiles and textile products \\
DC & Leather and leather products \\
DD & Wood and wood products \\
DE & Pulp, paper and paper products; publishing and printing \\
DF & Coke, petroleum products and nuclear fuel \\
DG & Chemicals, chemical products and man-made fibres \\
DH & Rubber and plastic products \\
DI & Other non-metallic mineral products \\
DJ & Basic metals and fabricated metal products \\
DK & Machinery and equipment not elsewhere classified \\
DL & Electrical and optical equipment \\
DM & Transport equipment \\
DN & Manufacturing not elsewhere classified \\
& Total manufacturing \\
D & \\
&
\end{tabular}

Weight per $1000^{1}$

$2003 \quad 19992000 \quad 2001 \quad 2002 \quad 2003 \quad 2004 \quad 2005 \quad 2006 \quad 2007$

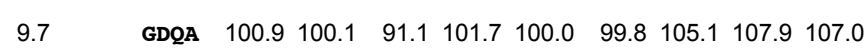

E Electricity, gas and water supply

C,D,E Total production

\begin{tabular}{|c|c|c|c|c|c|c|c|c|c|c|}
\hline 0.5 & CKZP & 132.7 & 112.5 & 112.9 & 105.9 & 100.0 & 85.9 & 67.2 & 64.4 & 57.6 \\
\hline 19.2 & CKZO & 117.4 & 113.5 & 107.1 & 105.8 & 100.0 & 91.5 & 82.4 & 75.1 & 73.2 \\
\hline 1.5 & CKZQ & 83.9 & 86.4 & 81.5 & 98.8 & 100.0 & 102.1 & 112.6 & 119.2 & 127.1 \\
\hline 21.1 & CKYX & 114.6 & 111.0 & 104.9 & 105.3 & 100.0 & 92.1 & 84.2 & 78.0 & 76.7 \\
\hline
\end{tabular}

\begin{tabular}{|c|c|c|c|c|c|c|c|c|c|c|}
\hline 21.1 & CKZA & 98.4 & 98.4 & 98.9 & 101.7 & 100.0 & 102.0 & 103.6 & 102.9 & 102.3 \\
\hline 4.2 & CKZB & 125.0 & 122.1 & 105.7 & 99.6 & 100.0 & 91.2 & 90.0 & 89.9 & 88.0 \\
\hline 0.5 & CKZC & 154.0 & 139.0 & 128.2 & 116.5 & 100.0 & 73.6 & 67.0 & 70.2 & 71.7 \\
\hline 2.6 & CKZD & 95.6 & 98.0 & 97.9 & 98.6 & 100.0 & 105.3 & 101.2 & 98.8 & 103.0 \\
\hline 19.5 & CKZE & 101.5 & 102.0 & 101.6 & 101.8 & 100.0 & 99.0 & 95.0 & 94.3 & 94.2 \\
\hline 2.3 & CKZF & 106.9 & 113.0 & 106.9 & 109.2 & 100.0 & 107.8 & 111.0 & 105.4 & 109.3 \\
\hline 15.9 & CKZG & 89.6 & 93.3 & 98.4 & 99.2 & 100.0 & 103.6 & 106.5 & 110.0 & 109.0 \\
\hline 7.4 & CKZH & 106.8 & 106.2 & 103.2 & 99.1 & 100.0 & 98.3 & 97.2 & 101.3 & 100.8 \\
\hline 5.3 & CKZI & 93.6 & 96.0 & 96.8 & 95.8 & 100.0 & 106.2 & 106.2 & 109.1 & 109.4 \\
\hline 14.6 & CKZJ & 101.1 & 103.0 & 100.2 & 101.3 & 100.0 & 102.7 & 103.6 & 105.1 & 106.1 \\
\hline 12.0 & CKZK & 102.7 & 102.4 & 104.4 & 98.8 & 100.0 & 105.9 & 109.3 & 116.1 & 121.3 \\
\hline 15.3 & CKZL & 111.5 & 127.0 & 119.6 & 103.9 & 100.0 & 102.2 & 98.0 & 98.3 & 99.3 \\
\hline 15.7 & CKZM & 102.9 & 99.9 & 98.4 & 95.4 & 100.0 & 105.3 & 105.2 & 111.3 & 111.1 \\
\hline 6.3 & CKZN & 101.0 & 100.5 & 98.9 & 100.1 & 100.0 & 100.2 & 100.7 & 101.7 & 104.5 \\
\hline 142.7 & CKYY & 101.6 & 103.9 & 102.5 & 100.3 & 100.0 & 102.2 & 102.0 & 103.8 & 104.5 \\
\hline 16.2 & CKYZ & 92.1 & 95.0 & 97.7 & 98.3 & 100.0 & 101.0 & 100.7 & 100.1 & 101.3 \\
\hline 180.0 & CKYW & 102.1 & 103.9 & 102.3 & 100.7 & 100.0 & 100.9 & 99.8 & 100.5 & 100.9 \\
\hline 58.6 & GDQB & 88.8 & 89.5 & 91.6 & 95.2 & 100.0 & 103.4 & 104.5 & 105.5 & 108 \\
\hline
\end{tabular}

G-Q Service industries

G Wholesale and retail trade (including motor trade); repair of motor vehicles, personal and household goods

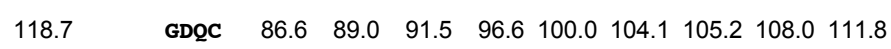

Hotels and restaurants

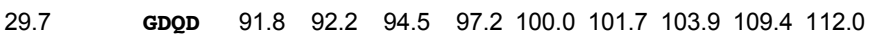

Transport, storage and communication Transport and storage Communication

Total

$\begin{array}{lllllllllll}46.3 & \text { GDQF } & 98.4 & 100.8 & 99.9 & 101.3 & 100.0 & 104.5 & 108.8 & 111.7 & 115.3\end{array}$

$\begin{array}{lllllllllll}29.1 & \text { GDOG } & 68.1 & 84.3 & 94.4 & 93.4 & 100.0 & 1025 & 107.6 & 109.8 & 113.1\end{array}$

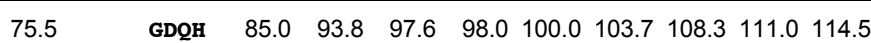

Financial intermediation

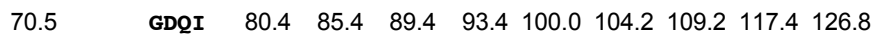

K Real estate, renting and business activities

Letting of dwellings, including imputed rent of owner occupiers

Other real estate, renting and business activities

K Total

$\begin{array}{lllllllllll}68.3 & \text { GDQL } & 95.2 & 96.5 & 97.4 & 98.3 & 100.0 & 100.4 & 101.1 & 102.6 & 103.2\end{array}$ $\begin{array}{lllllllllll}160.5 & \text { GDQK } & 82.0 & 89.6 & 95.2 & 95.5 & 100.0 & 106.6 & 113.5 & 121.4 & 129.8\end{array}$

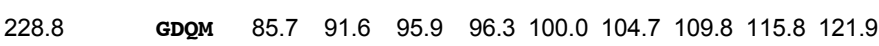

$\mathrm{L} \quad$ Public administration and defence (PAD)

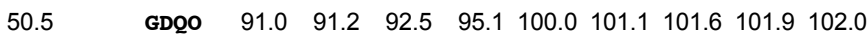

M Education

$\begin{array}{lllllllllll}57.5 & \text { GDQP } & 95.2 & 96.0 & 97.1 & 99.1 & 100.0 & 99.4 & 99.8 & 99.3 & 98.8\end{array}$

$\mathrm{N} \quad$ Health and social work

$\begin{array}{lllllllllll}69.5 & \text { GDQQ } & 86.1 & 89.0 & 92.4 & 96.2 & 100.0 & 103.7 & 106.1 & 108.7 & 112.4\end{array}$

$\mathrm{O}, \mathrm{P}, \mathrm{Q}$ Other social and personal services private households with employees and extra-territorial organisations

G-Q Total service industries

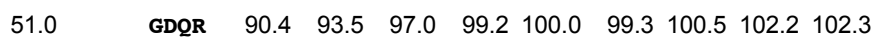

$\begin{array}{lllllllllll}751.7 & \text { GDQS } & 86.9 & 91.1 & 94.3 & 96.6 & 100.0 & 103.2 & 106.3 & 110.2 & 114.3\end{array}$

1 The weights shown are in proportion to total gross value added (GVA) in 3 See footnote 2 to Table 2.3

2003 and are used to combine the industry output indices to calculate the

totals. For 2003 and earlier, totals are calculated using the equivalent weights for the previous year (e.g. totals for 2003 use 2002 weights) Weights may not sum to totals due to rounding.

2 As GVA is expressed in index number form, it is inappropriate to show as a statistical adjustment any divergence from the other measures of GDP. Such an adjustment does, however, exist implicitly. 


\subsection{Employment: by industry}

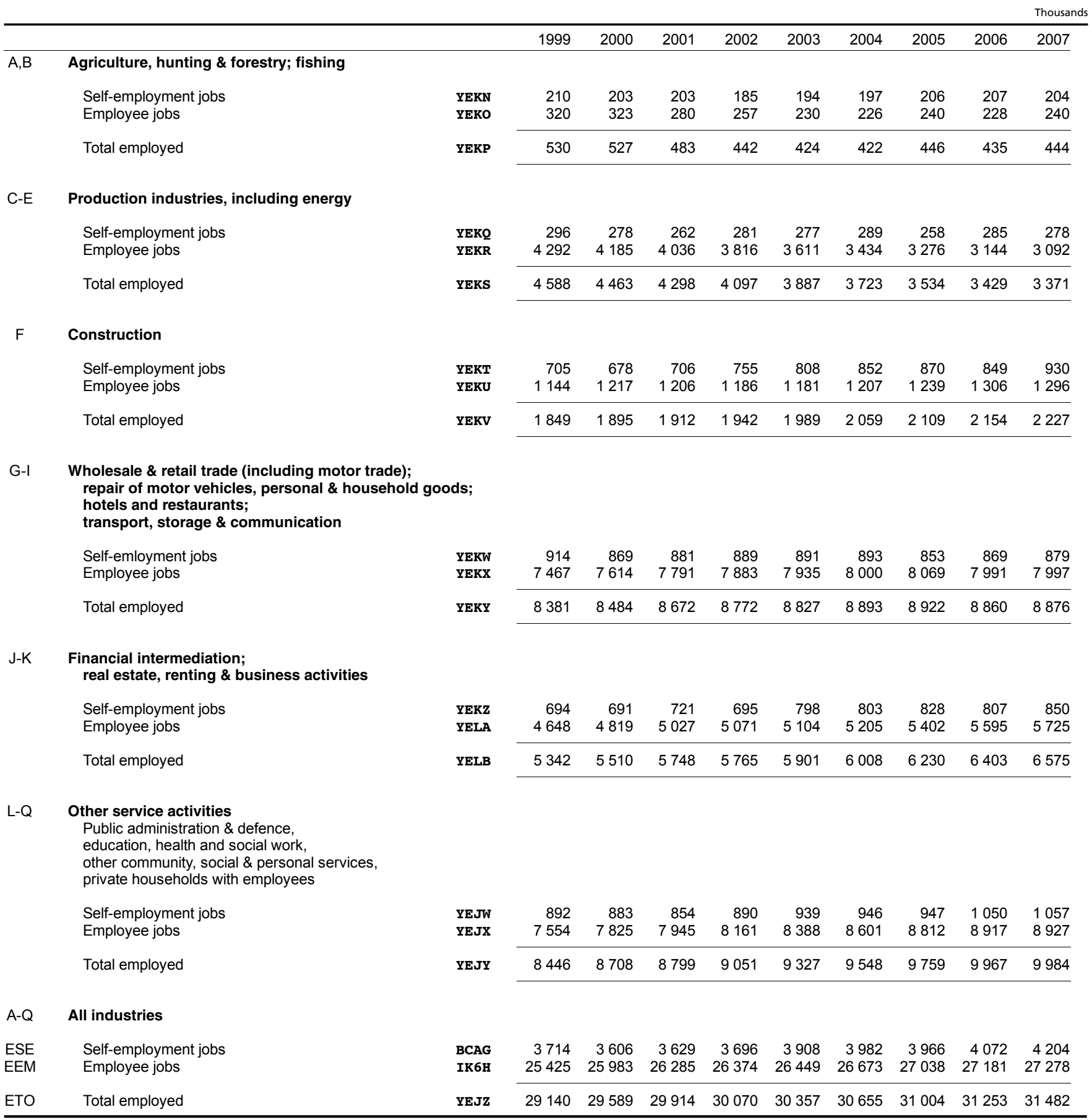

1 Data sources are: Labour Force Survey for self-employed; employer sur-

veys for employees. Figures as at June of each year. 